PNNL-13261

\title{
Description of Work for Drilling at the 183-DR Site in Support of the In Situ Gaseous Reduction Test
}

\author{
E. C. Thornton \\ K. B. Olsen \\ R. Schalla
}

June 2000

Prepared for

the U.S. Department of Energy

under Contract DE-AC06-76RLO 1830

Pacific Northwest National Laboratory

Richland, Washington 99352 



\section{DISCLAIMER}

This report was prepared as an account of work sponsored by an agency of the United States Government. Neither the United States Government nor any agency thereof, nor any of their employees, make any warranty, express or implied, or assumes any legal liability or responsibility for the accuracy, completeness, or usefulness of any information, apparatus, product, or process disclosed, or represents that its use would not infringe privately owned rights. Reference herein to any specific commercial product, process, or service by trade name, trademark, manufacturer, or otherwise does not necessarily constitute or imply its endorsement, recommendation, or favoring by the United States Government or any agency thereof. The views and opinions of authors expressed herein do not necessarily state or reflect those of the United States Government or any agency thereof. 


\section{DISCLAIMER}

\section{Portions of this document may be illegible in electronic image products. Images are produced from the best available original document.}




\section{Summary}

In Situ Gaseous Reduction is a technology currently being developed by the U.S. Department of Energy for the remediation of soil waste sites contaminated with hexavalent chromium. Prior work suggests that a candidate for application of this approach is the 183-DR site at Hanford. However, deep vadose zone drilling is needed to verify the presence of a hexavalent chromium source and to determine the concentration levels and spatial distribution of contamination. This document presents the requirements associated with drilling one to two vadose zone boreholes at the $183-\mathrm{DR}$ site to obtain this information. If hexavalent chromium is determined to be present at levels of at least $10 \mathrm{ppm}$ in the vadose zone in one of the initial boreholes, that hole will be completed for gas injection and six additional gas extraction boreholes will be drilled and completed. This network will be used as a flowcell for performing a gas treatment test at the site. 


\section{Acknowledgments}

This work is funded by the Office of Science and Technology, within the U.S. Department of Energy's Office of Environmental Management, under the Subsurface Contaminants Focus Area. The authors wish to acknowledge the contributions of a number of individuals who participated in or supported the preparation of this document: Bill Bonner, Jim Bush, Joe Devary, John Fruchter, Tyler Gilmore, Ron Smith, and Mark Williams of Pacific Northwest National Laboratory; John April, Ron Jackson, Greg Mitchem, and Scott Petersen of Bechtel Hanford Inc.; Jim Hanson, Scott McMullin, and Arlene Tortoso of the U.S. Department of Energy; and Mark Sturges and John Wimett of CH2M Hill Hanford, Inc. 



\section{Contents}

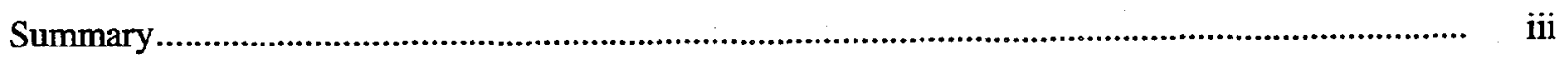

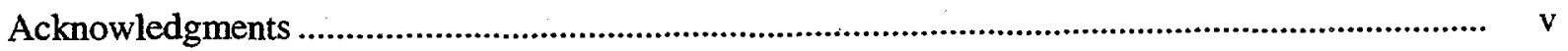

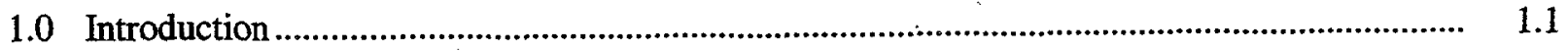

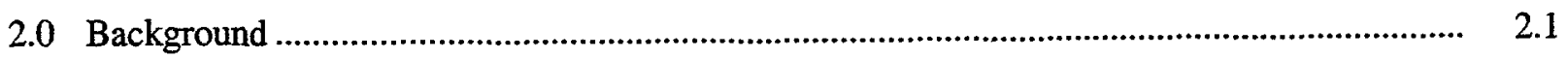

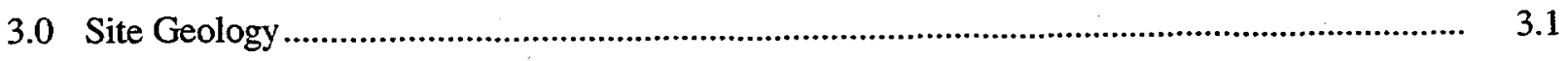

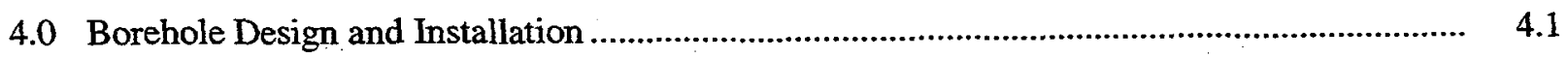

5.0 Vadoze Zone and Groundwater Sampling and Analysis in Support of Site Characterization ........................................................................................................ 5.1

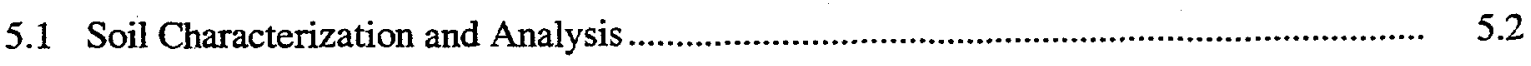

5.1.1 On-Site Laboratory Analysis ........................................................................... 5.2

5.1.2 Offsite Chemical Analyses of Soil Samples ...................................................... 5.4

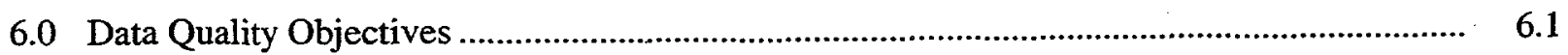

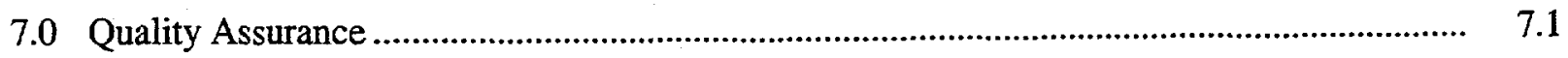

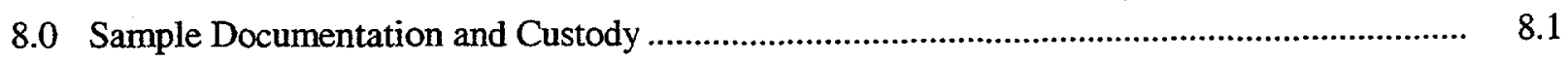

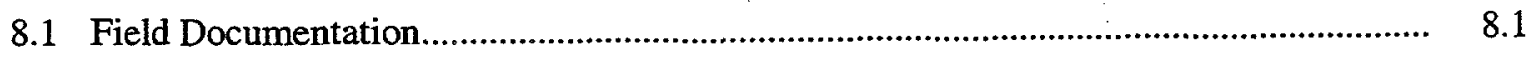

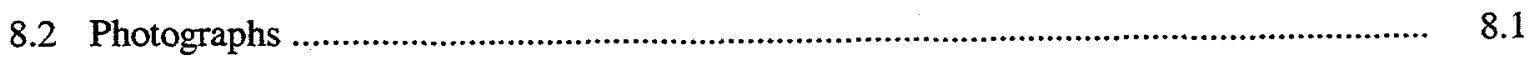

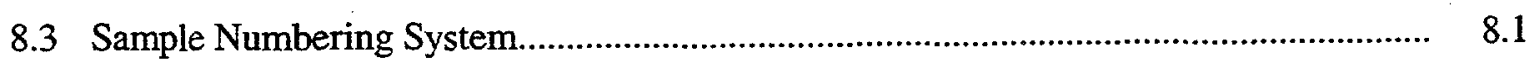

8.4 Laboratory Documentation ................................................................................. 8.1

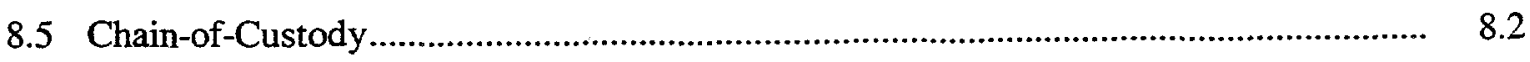

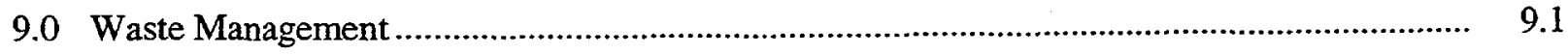

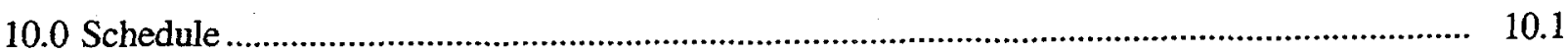


11.0 General Requirements

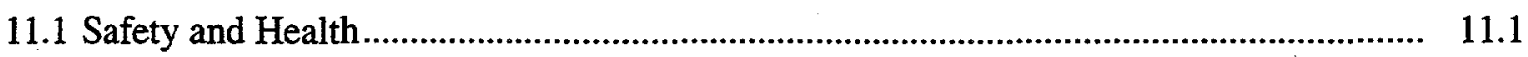

11.2 Technical Procedures/Specifications ................................................................... 11.1

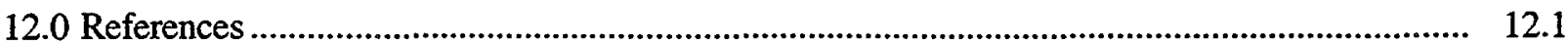




\section{Figures}

2.1 Conceptual Model of the In Situ Gas Treatment System and Wellfield Network

2.2 Facilities and $\mathrm{Cr}(\mathrm{VD})$ Groundwater Plumes in the 100-D Area ............................................ 2.3

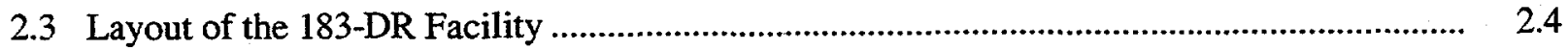

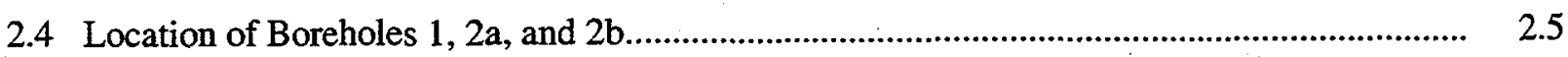

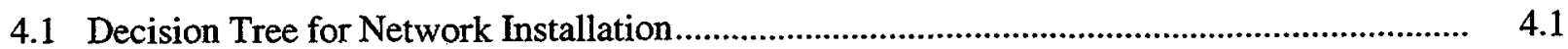

4.2 ISGR Well Design Schematic (Phase 1) ....................................................................... 4.2

4.3 Configuration of the Wellfield Network and Soil Sampling Locations ............................... 4.3

\section{Tables}

5.1 Phase 1 and 2 Soil Samples and Analytical and Geotechnical Methods for Site Characterization

5.2 Post-Test Soil Samples and Analytical and Geotechnical Methods for Site Characterization

6.1 Chromium Analytical Methods, Quantitation Limits and Precision and Accuracy Guidelines

6.2 Analytical Methods for Waste Designation

\section{Attachments}

1 183-DR ISGR Drilling Waste Designation DQO Summary Report

2 183-DR Site Map

3 Borehole SOW and Drilling Specifications

4 Variance Request 


\subsection{Introduction}

This document describes field activities associated with installation of boreholes to verify the presence of hexavalent chromium in the vadose zone at the former location of the 183-DR facility, a water treatment plant, in the 100 D/DR Area of the U.S. Department of Energy (DOE) Hanford Site, Richland, Washington. If the zone of contamination is identified, treatment by injection of a reactive gas (In Situ Gaseous Reduction or ISGR) has been proposed. The ISGR approach is expected to have a significant effect on local groundwater by immobilizing chromium in the vadose zone. Thus, sampling and analysis of vadose zone samples to support data collection needs for the 183-DR ISGR demonstration will be completed as outlined in this drilling description of work. A draft treatability test plan has also been prepared that describes technical activities and requirements associated with the gas treatment demonstration. ${ }^{(a)}$

The first two boreholes to be installed (Phase 1 Drilling) will provide data to determine whether sufficient hexavalent chromium contamination exists at the 183-DR site to warrant a full-scale ISGR treatability test. If hexavalent chromium concentrations exceed $10 \mathrm{ppm}$ in vadose zone sediment material below 15 feet in the soil column, one of these boreholes will be designated as the gas injection borehole, and Phase 2 Drilling will be initiated. Activities under Phase 2 include the installation of six extraction boreholes around the injection borehole and an optional pre-test characterization borehole within the network. Also described in this description of work are activities associated with drilling and soil sampling of three boreholes during post-treatment characterization activities (Phase 3 Drilling).

Bechtel Hanford Incorporated (BHI) will be responsible for drilling activities described in this document. Pacific Northwest National Laboratory (PNNL) will be responsible for geological logging, preparation of borehole construction records, and sediment and groundwater sampling and analysis.

English units are used in this report because they are used by drillers to measure and report depths and well construction details. The conversion to metric can be made by multiplying feet by 0.3048 to obtain meters or by multiplying inches by 2.54 to obtain centimeters.

(a) Thornton, E. C., K. B. Olsen, T. J Gilmore, R. Schalla, K. Cantrell, S.W. Petersen, and M. Oostrom. 2000. Treatability Test Plan for In Situ Gaseous Reduction at the Hanford 183-DR Site. Pacific Northwest National Laboratory, Richland, Washington. 


\subsection{Background}

The development and deployment of the ISGR technology was funded by the U.S. Department of Energy EM-50 Subsurface Contaminant Focus Area under Technical Task Plan (TTP) RL38SS42, In Situ Chemical Treatment of Soils by Gaseous Reduction, to PNNL. This approach involves the preparation of the reactive gas mixture (diluted hydrogen sulfide in air or nitrogen) by a skid-mounted gas treatment system and injection of the treatment gas into chromate-contaminated soil through a borehole, as illustrated in Figure 2.1. The mixture is drawn through the soil by a vacuum applied to extraction wells situated at the periphery of the flow cell. As the gas mixture contacts the contaminated soil, hexavalent chromium is reduced to the trivalent oxidation state, which results in immobilization and detoxification of the chromium. Residual hydrogen sulfide is then scrubbed from the extracted gas mixture by the gas treatment system and the clean air or nitrogen released to the environment.

A small-scale field demonstration of this approach was previously completed by PNNL at a small waste site located at the U.S. Department of Defense (DoD) White Sands Missile Range, New Mexico (Thornton et al. 1999). This pilot demonstration was effective in treating hexavalent chromium at the test site and was successfully completed without any measurable release of treatment gas to the environment.

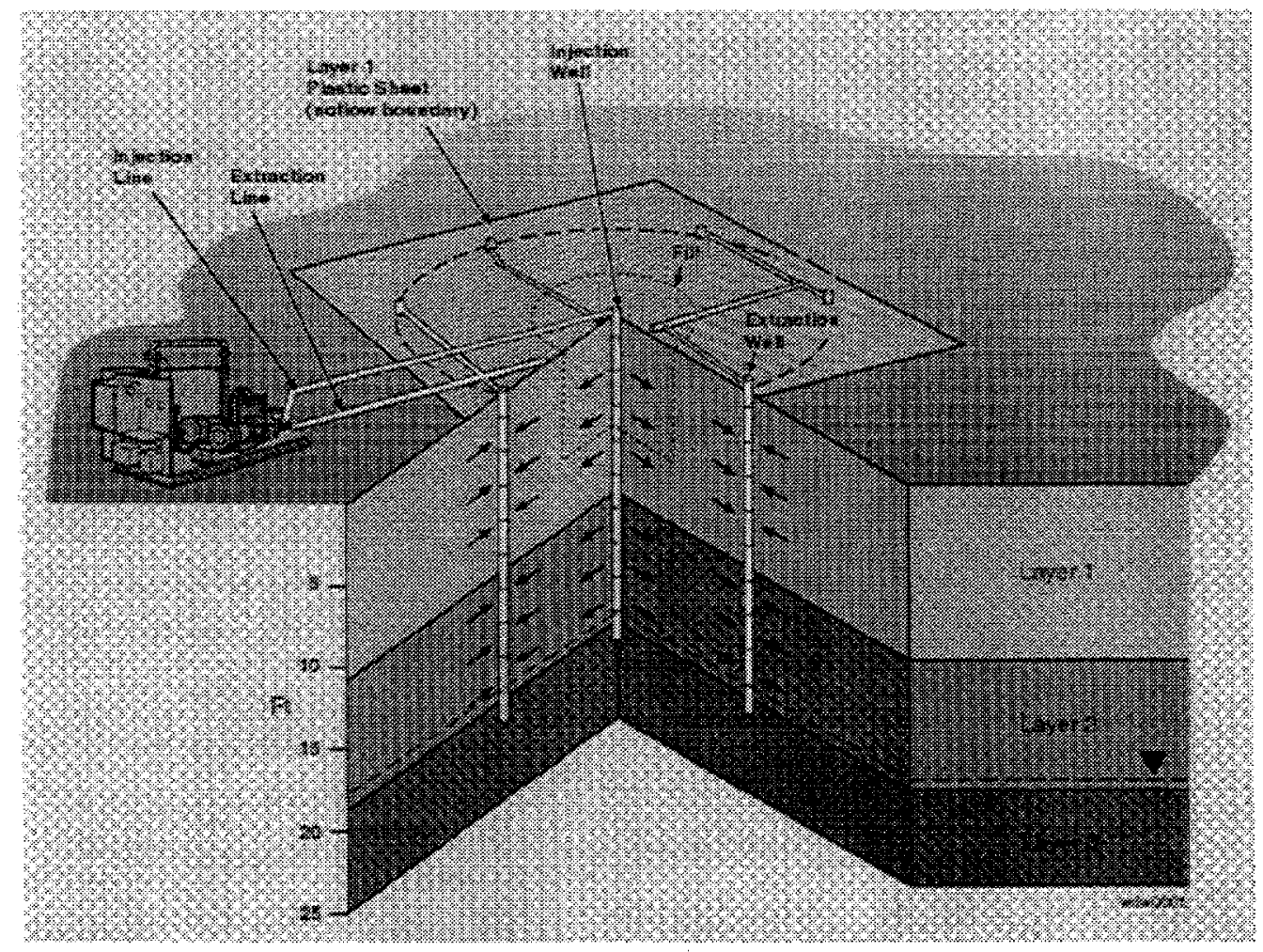

Figure 2.1. Conceptual Model of the In Situ Gas Treatment System and Wellfield Network 
A demonstration area within the Department of Energy's (DOE) Hanford Site in southeastern Washington State has been identified that will be utilized for the initial deployment of the ISGR technology at a significantly larger scale. The need for the ISGR technology at the Hanford Site is formally recognized in Site Technology Coordinating Group (STCG), Need \#RL-SS11, Cost-Effective, In Situ Remediation of Hexavalent Chromium in the Vadose Zone. The ISGR approach to soil remediation has been presented to stakeholders in meetings with the Hanford STCG and the performance of a treatability test at the Hanford Site has been endorsed by the STCG Management Council. A draft treatability test plan also was prepared to support the Hanford demonstration and is currently being reviewed.

The proposed demonstration site is located in the $100 \mathrm{D}$ Area at the former location of the 183-DR Head House (Figure 2.2). A large groundwater chromate plume presently exists downgradient of the 183-DR site, strongly suggesting that the area around $183-\mathrm{DR}$ is the source of the plume (Rohay et al. 1999 and Figure 2.2). The 183-DR facility was constructed in 1950 to treat water from the Columbia River that was a source of cooling water for the DR Reactor (WHC 1993). Primary treatment operations included coagulation/flocculation of sediment and chlorination (Figure 2.3). This facility stockpiled sodium dichromate solution, which was delivered by rail to a dichromate transfer station and transferred to $183-D R$ by chemical lines. Sodium dichromate was added to the processed cooling water at concentrations of several parts per million ( $\mathrm{ppm}$ ) after filtering and before going into clear wells, and was used as a corrosion inhibitor (Richards 1953).

The treatment plant was demolished in 1978. This involved removal of surface structures and filling the sedimentation basins with debris and backfill. No significant contamination of soil by hexavalent chromium was described in historical reports. However, recent shallow vadose zone sampling activities have indicated that significant concentrations of trivalent chromium and minor hexavalent chromium contamination exists at the site (Thornton et al. 2000). In that study, vadose zone characterization was undertaken at 183-DR using geoprobe and cone penetrometer equipment and by track hoe trenching (Figure 2.4). This provided additional shallow ( $\leq 20 \mathrm{ft}$ ) vadose stratigraphic information, but very little chromate contamination was identified. However, minor levels of hexavalent chromium and high levels of total chromium ( $\sim 650 \mathrm{ppm})$ were detected in soil samples collected in a trench on the northeastern corner of the head house and just north of the chromate storage tanks (see Figures 2.3 and 2.4). This area of contamination is the proposed location of the first exploration borehole (see Figure 2.4), which is needed to determine if hexavalent chromium contamination is present deeper in the vadose zone at 183-DR. 


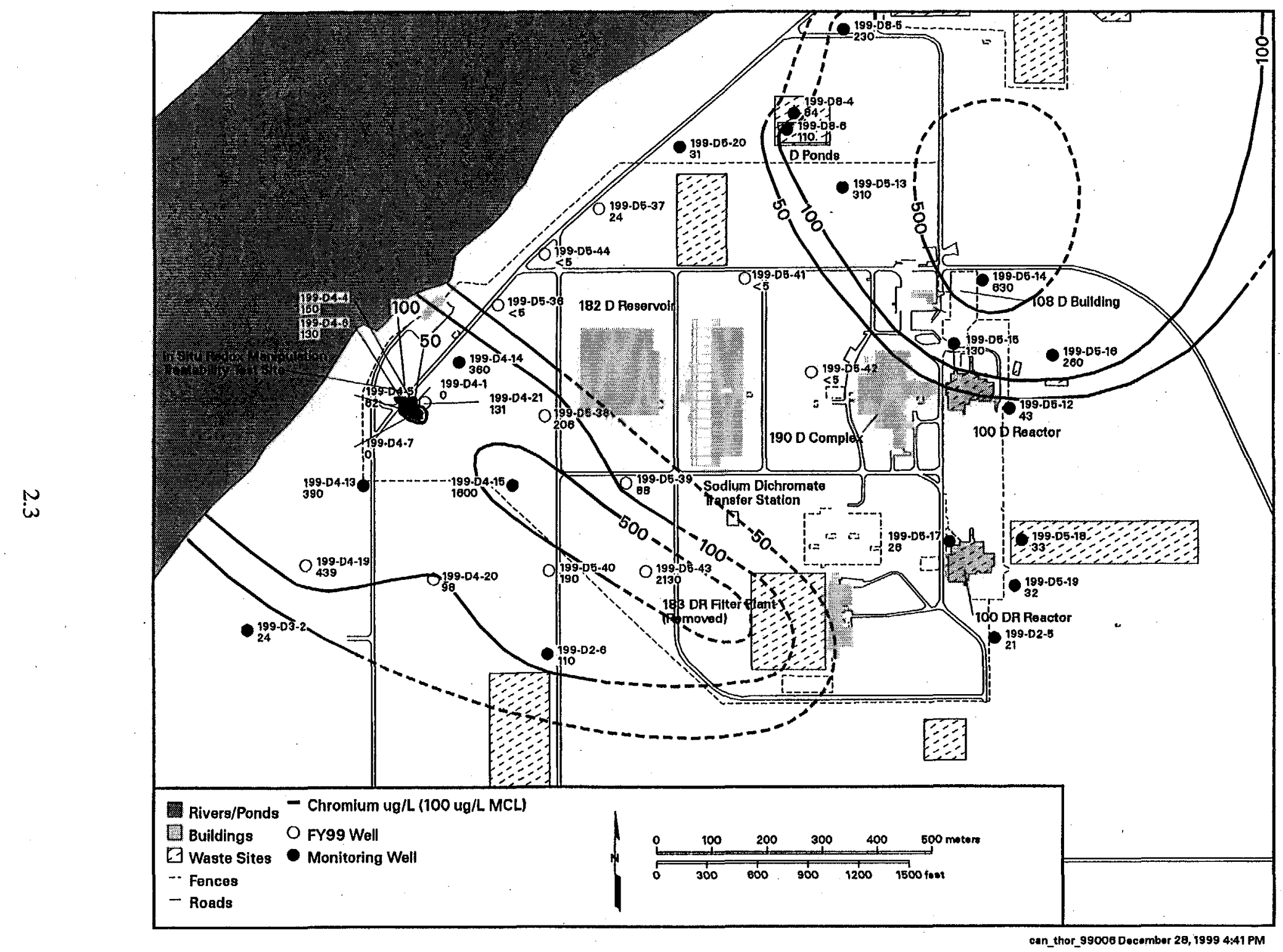

Figure 2.2. Facilities and $\mathrm{Cr}(\mathrm{VI})$ Groundwater Plumes in the 100-D Area 


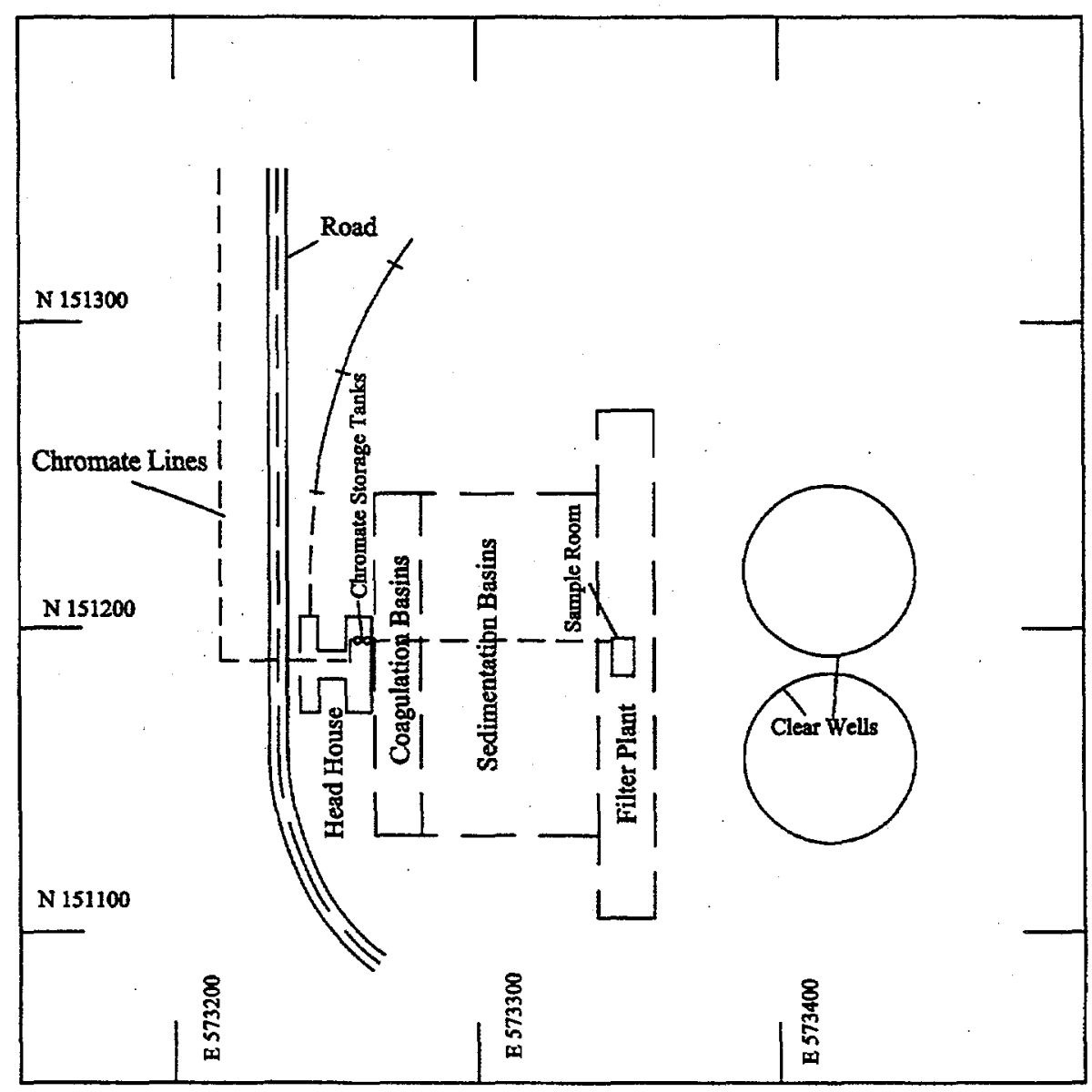

Figure 2.3. Layout of the 183-DR Facility. Coordinate System: State Plane NAD83 (meters). 


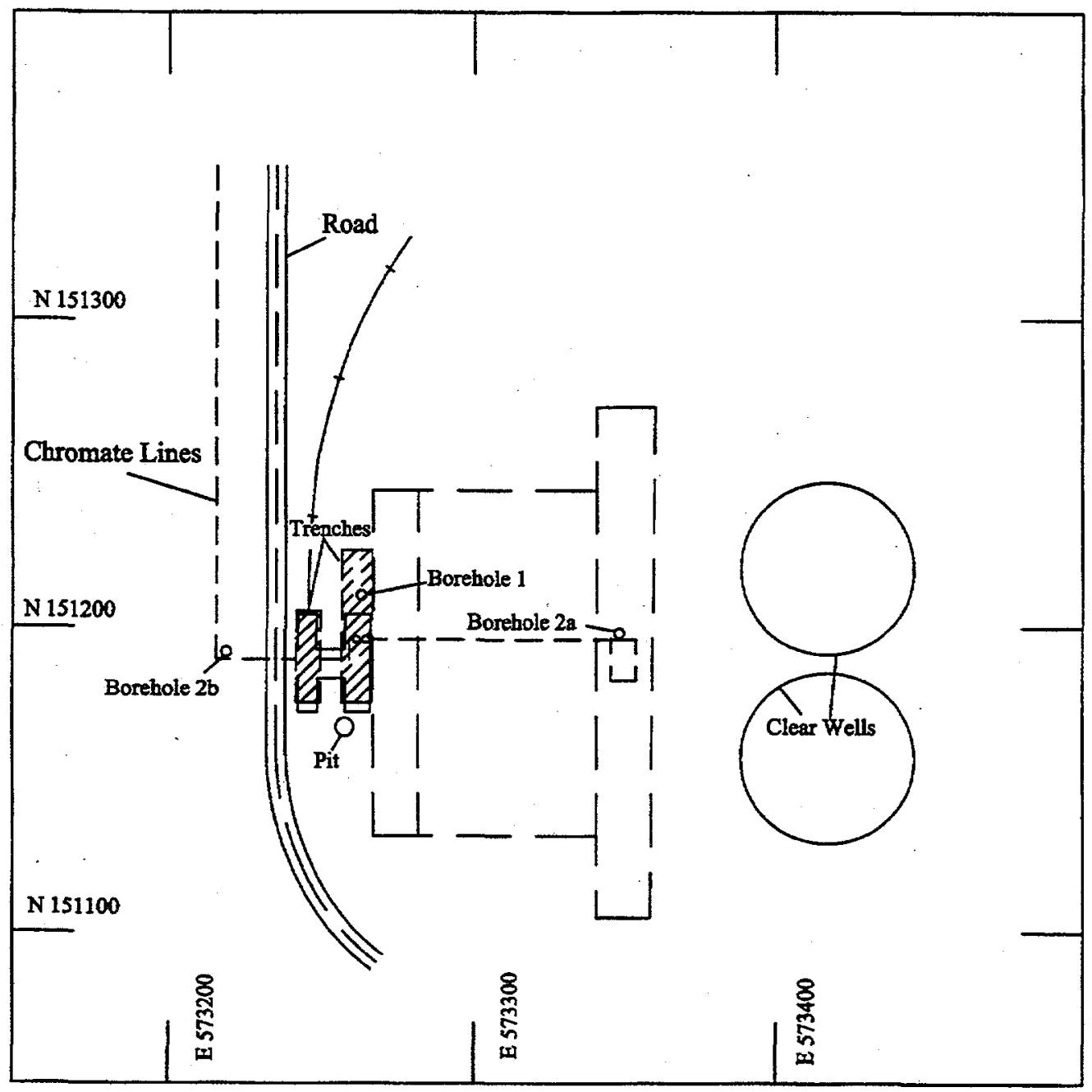

Figure 2.4. Location of Boreholes $1,2 a$, and $2 b$ 


\subsection{Site Geology}

The stratigraphic units associated with the vadose zone and unconfined aquifer in the vicinity of the 183-DR site include localized Holocene surficial deposits and backfill, the informally defined Hanford formation, and the Ringold Formation. The first 5 to $6 \mathrm{~m} \mathrm{(15}$ to $20 \mathrm{ft}$ ) at the site is composed of backfill material containing broken concrete and reinforcing steel with the last $1 \mathrm{~m}(3 \mathrm{ft})$ poured-in-place reinforced concrete.

Based on geological logging performed during the drilling of groundwater monitoring wells in the $100 \mathrm{D}$ Area, the Hanford formation is generally present to a depth of about $17 \mathrm{~m}$ ( 0 to $55 \mathrm{ft}$ ); a coarsegrained unit of the Ringold is present from 17 to $30 \mathrm{~m}$ (55 to $98 \mathrm{ft}$ ); and a fine-grained unit of the Ringold Formation is present below $30 \mathrm{~m}(98 \mathrm{ft}$ ). Hanford formation sediments consist of 0.6 to $3.4 \mathrm{~m} \mathrm{(} 2$ to $11 \mathrm{ft}$ ) thick interbedded sand and sandy gravel layers. Coarse-grained Ringold Formation Unit $\mathrm{E}$ deposits underlie the Hanford formation in the vicinity of 183-DR; these deposits consist of sandy gravels to sandy silty gravels. The Ringold Upper Mud Unit occurs locally at a depth of about $32 \mathrm{~m}$ (105 ft) and acts as an aquitard that forms the base of the unconfined aquifer.

Specific geologic information for the 183-DR site is available from the borehole log for well 199-D5-43 (see Figure 2.2) that was drilled to a total depth of $34.4 \mathrm{~m}(112.5 \mathrm{ft}$ ). A sandy gravel unit is present to a depth of $14.5 \mathrm{~m}(47.5 \mathrm{ft})$, a gravely sand from 14.5 to $32.6 \mathrm{~m}$ ( 47.5 to $107 \mathrm{ft}$ ), and a silt (Ringold Upper Mud Unit) from 32.6 to $34.4 \mathrm{~m}$ (107 to $112.5 \mathrm{ft}$ ). The top of the unconfined aquifer is located at about $24 \mathrm{~m}(80 \mathrm{ft})$ below ground surface within the Ringold Unit $\mathrm{E}$ at 183-DR. 


\subsection{Borehole Design and Installation}

Under Phase 1 drilling activities, one or two characterization boreholes will be installed at the 183-DR site. These boreholes will be used to verify the presence of treatable quantities of hexavalent chromium in the vadose zone at the site. Borehole 1 will be located to the north of the former location of 183-DR (see Figure 2.4). Figure 4.1 presents a logic diagram, which will be used under Phase 1 to determine the location of the second borehole, if needed, and subsequent activities under Phase 2 . If significant vadose zone contamination ( $>10 \mathrm{ppm}$ chromium [VI]) is found below $15 \mathrm{ft}$, the first borehole (BH-1) will become the central injection borehole and will be completed for groundwater sampling and

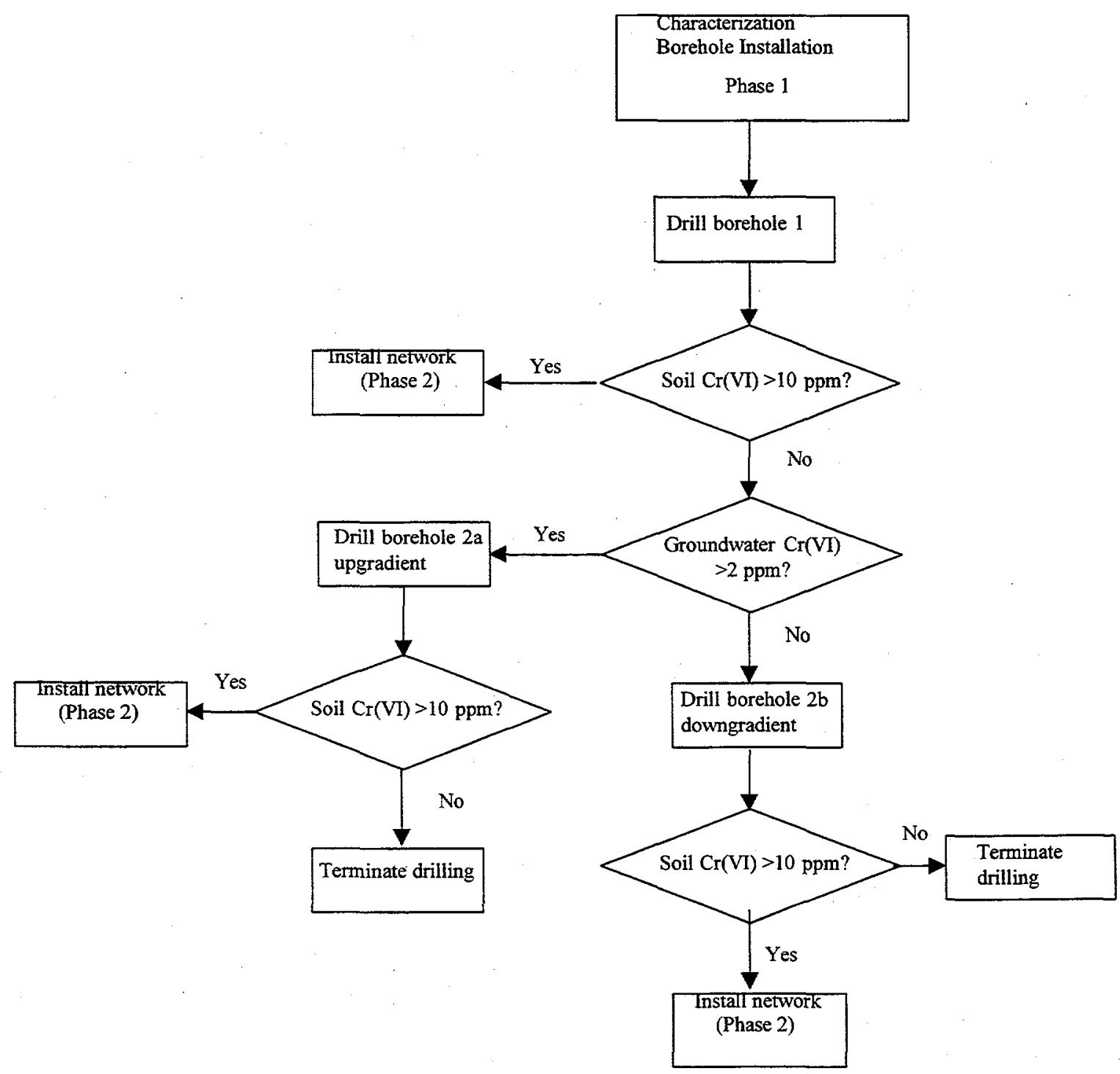

Figure 4.1. Decision Tree for Network Installation 
gas injection as shown in Figure 4.2. This borehole will contain four 2-inch PVC lines with screens for gas injection or extraction and a fifth line that will access the groundwater table to permit collection of groundwater samples (see Figure 4.2 and Appendix C). Groundwater samples will be collected using a submersible pump to develop and sample the well. If $>10 \mathrm{ppm}$ chromium (VI) is measured in vadose zone samples from this borehole, the wellfield will be completed as shown in Figure 4.3 under Phase 2.
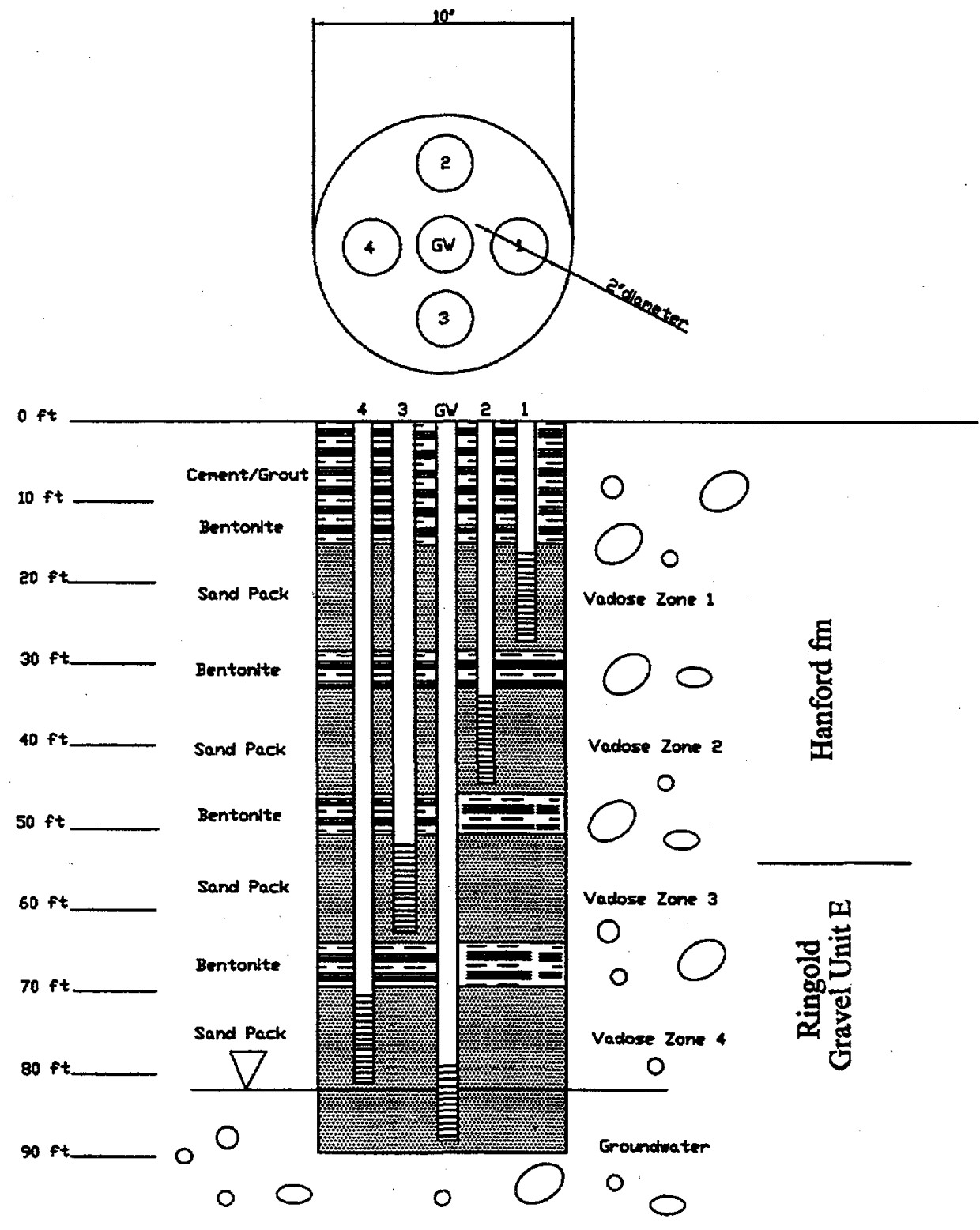

Figure 4.2. ISGR Well Design Schematic (Phase 1) 


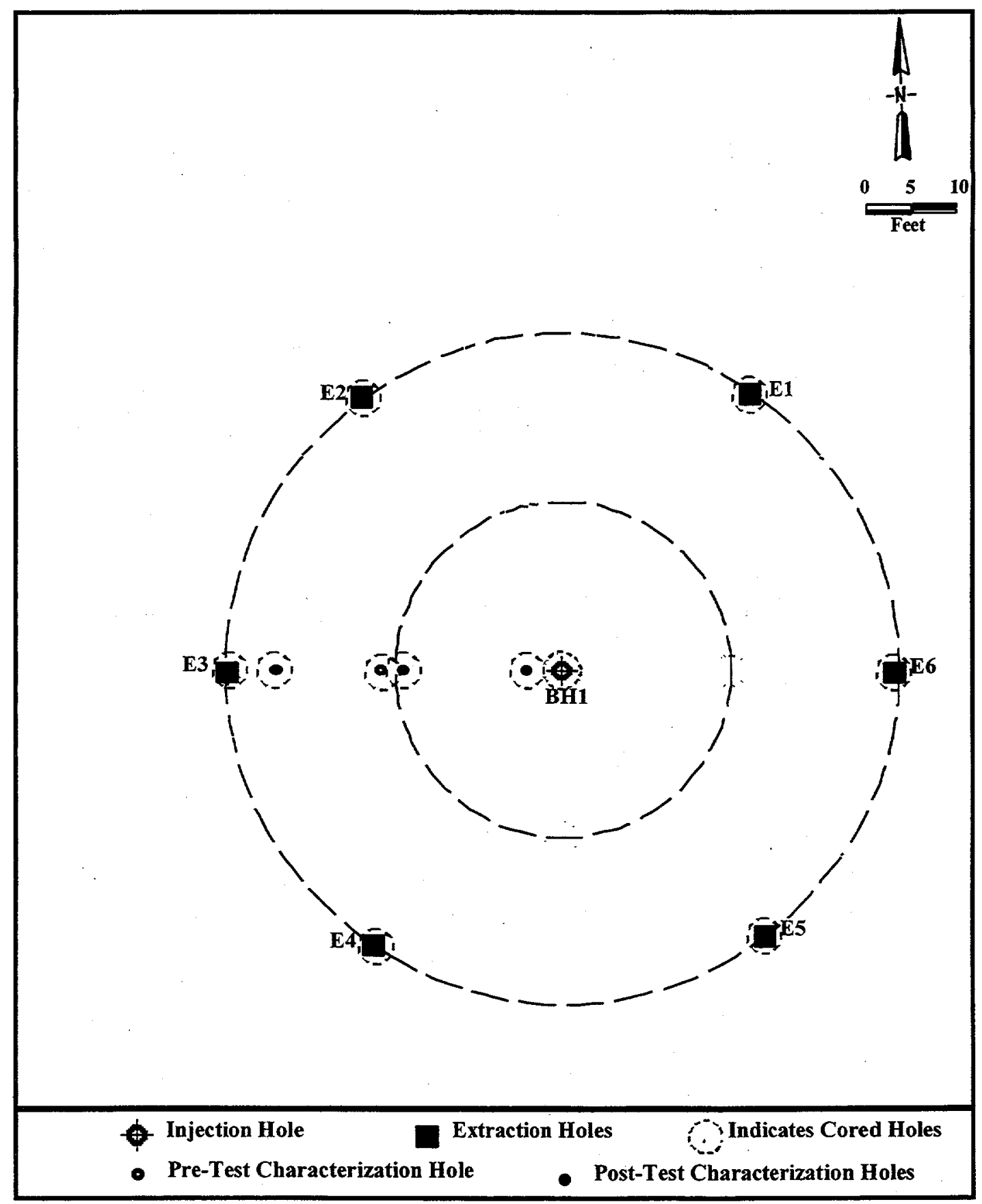

Figure 4.3. Configuration of the Wellfield Network and Soil Sampling Locations

If no vadose zone contamination is found in the first borehole, the borehole will be completed with only one line to groundwater and samples will be obtained. If the groundwater concentration exceeds

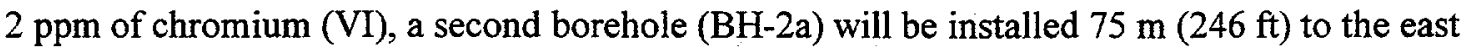
(upgradient) in the approximate location of the filter building. If no vadose zone chromium contamination is found in the first borehole (BH-1) and groundwater chromium concentrations are below $2 \mathrm{ppm}$, the 
second characterization borehole (BH-2b) will be installed $50 \mathrm{~m}(164 \mathrm{ft})$ to the west (downgradient) at a location where the chromate line turns toward the 183-DR head house. If greater than $10 \mathrm{ppm}$ chromium (VI) is present in soil samples from boreholes $\mathrm{BH}-2 \mathrm{a}$ or $\mathrm{BH}-2 \mathrm{~b}$, that hole will be completed as the central injection borehole and the network installed under Phase 2. If chromium (VI) is not encountered during the drilling of either borehole, drilling will be terminated and alternative options will be developed. The decision to stop after Phase 1 versus proceeding to Phase 2 will be made by PNNL and DOE project staff based on the logic presented above and will occur within two days to minimize subcontractor standby costs.

Either one or two boreholes will be drilled during Phase 1 from the ground surface to $2 \mathrm{~m}(7 \mathrm{ft})$ below the water table, which is about $25 \mathrm{~m}(82 \mathrm{ft})$ below ground surface. Drilling will be by either the sonic or cable tool methods. Continuous split spoon sampling will be conducted and samples collected and analyzed as indicated in Sections 5 and 9. Since these boreholes will not be completed according to WAC 173-160 standards if chromium (VI) is found, a variance has been obtained from Washington State Department of Ecology (WDOE) (Attachment 4). In the event no chromium (VI) is found in the vadose zone sediments in either of these boreholes, one of the boreholes will be completed as a groundwater resource protection well, according to WAC 173-160.

If significant chromium (VI) is identified in the borehole soil samples obtained during drilling at the 183-DR site, it is planned to perform geophysical logging of one of the Phase 1 boreholes. High purity germanium (HPGe) gamma and neutron moisture logging will be performed in one borehole if chromium (VI) is identified (note: this activity is contingent upon approval of funding specific to this task). This information will be used to identify stratigraphic changes and to measure changes in vadose zone moisture content with depth at 183-DR.

If $>10 \mathrm{ppm}$ chromium (VI) is found in either of the Phase 1 boreholes, an additional six boreholes will be drilled during Phase 2. Cuttings will be collected during the drilling of these six boreholes for analysis of chromium (VI). These boreholes will be drilled to groundwater and completed with four piezometers (2-inch PVC lines) in the vadose zone to be used for gas extraction.

The completed wellfield network will consist of the central injection borehole drilled during Phase 1 and six Phase 2 extraction boreholes located in a hexagonal pattern around the injection borehole (see Figure 4.3). The radius of the network is expected to be about $9 \mathrm{~m}(30 \mathrm{ft})$ and will extend to the groundwater table at a depth of about $25 \mathrm{~m}(82 \mathrm{ft})$. In addition, an optional borehole internal to the network may be installed, if the first exploration borehole becomes the injection borehole (i.e., the maximum number of boreholes drilled will be eight).

It is also expected that three Phase 3 post-treatment characterization boreholes will be drilled after the ISGR demonstration for collection of soil samples only (see Figure 4.3). These samples also will be analyzed for hexavalent chromium. Comparison of pre- versus post-treatment hexavalent chromium concentrations of site soils will be used to assess the effectiveness of the gas treatment demonstration (Thornton et al. 1999). 


\subsection{Vadoze Zone and Groundwater Sampling and Analysis in Support of Site Characterization}

Up to eight boreholes may be drilled during Phase 1 and 2 pre-treatment drilling effort and three additional boreholes will be drilled during Phase 3 to obtain post-treatment characterization data. Soil samples will be analyzed as indicated in Section 5.1 to provide site characterization and soil treatment information. Waste management associated with Phase 1 and 2 drilling activities are addressed in Section 9.

All boreholes will be drilled using a non-circulating drilling technique (i.e., the sonic or cable tool methods). Continuous split spoon sampling will be performed during Phase 1 drilling (first two boreholes) from the base of fill/debris to groundwater, which is approximately the interval from 5 to $25 \mathrm{~m}$ ( 15 to $82 \mathrm{ft}$ ) below ground surface. The Phase 1 characterization boreholes will be heavily characterized

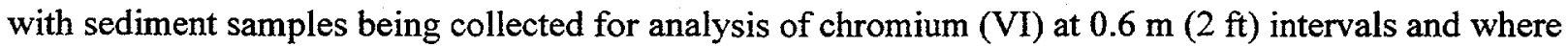
color changes are noted. The Phase 2 extraction boreholes will be less intensely characterized with samples being collected from cuttings at $1.5 \mathrm{~m}(5 \mathrm{ft})$ intervals for chromium (VI) analysis. The three post-test Phase 3 boreholes will be continuously split spoon sampled and analyzed for chromium (VI) at a

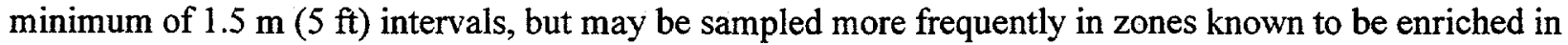
chromium.

Field sampling and analytical procedures for the Phase 3 post-test characterization activities will be the same as the pre-test activities with the exception of using an argon gas blanket during drilling of the post-characterization boreholes. Argon will prevent exposure of the soil samples to atmospheric oxygen. This will prevent metals from potentially reoxidizing during the sampling process. Immediately following withdrawal from the borehole the split spoon sampler will be placed into an argon filled glove box where aliquots of the core will be removed and placed into sample bottles. These bottles will be sealed and transported to an inert atmospheric glove box located in the PNNL Sigma 5 building.

The boreholes will be drilled in an area previously occupied by the 183-DR head house, coagulation and sedimentation basins, and the filter plant. When these facilities were demolished a wrecking ball was used and the construction debris was dumped or dropped into the basins. The base of the basins is estimated to be between 4 and $5 \mathrm{~m}$ (13 and $15 \mathrm{ft}$ ) below ground surface. Therefore, no samples will be collected from ground surface to $5 \mathrm{~m}(15 \mathrm{ft})$ below ground surface. When sampling begins below the base of the basin in native soil, Phase 1 soil samples will be collected with a $0.6 \mathrm{~m}$ ( $2 \mathrm{ft})$ long, split spoon sampler equipped with a lexan liner. When the lexan liner is removed from the split spoon, mineralogy, stratigraphy, and visual inspection of soil moisture will be recorded into a field notebook or daily borehole log. Discrete soil samples will be removed from the lexan liner with a stainless steel spatula at 0.6-m (2-ft) intervals and at lithologic and color changes from the first two boreholes drilled. The remaining Phase 2 boreholes will be sampled at $1.5-\mathrm{m}(5-\mathrm{ft})$ intervals from the cuttings. For the $1.5-\mathrm{m}$ (5-ft) interval samples at least $200 \mathrm{~g} \mathrm{(7} \mathrm{oz)} \mathrm{of} \mathrm{sample} \mathrm{will} \mathrm{be} \mathrm{composited} \mathrm{from} \mathrm{the} \mathrm{cuttings} \mathrm{collected} \mathrm{over}$ the interval (e.g., from the same geologic horizon). This sample will then be split, with at least $100 \mathrm{~g}$ $(3.5 \mathrm{oz})$ being placed in the appropriate sample bottles and approximately $100 \mathrm{~g}(3.5 \mathrm{oz})$ placed in a 
moisture proof container for moisture content analysis. Duplicate samples will be collected for about $10 \%$ of those samples being sent off-site for analyses. Table 5.1 lists the appropriate sample container and preservative methods of each analysis. Prepared labels will be affixed to all sample containers. Information presented on the sample label will include the following:

- project name

- collecting date

- name of sampler

- sample tracking number

- nature of material (soil or groundwater)

- depth

- requested analyses or test.

Soil samples will be placed into 60 -ml (2-oz.) wide-mouth, glass bottles with Teflon-lined lids (to be supplied by PNNL). Pebbles and debris will be eliminated from the sample.

Groundwater samples will also be collected from the completed boreholes and analyzed for chromium (VI) by EPA Method 7196.

\subsection{Soil Characterization and Analysis}

Soil samples collected during pre- and post-test borehole installation will be analyzed for the parameters listed in Table 5.1 and Table 5.2, respectively. An on-site PNNL geologist will conduct geologic logging and sampling activities. Mineralogy, stratigraphy, and visual inspection of soil moisture will be recorded onto field record sheets and/or notebooks in accordance with procedure PNL-DO-01 (in PNL 1993) or its equivalent. In addition, borehole geophysical logging will be conducted, provided significant concentrations of chromium (VI) are identified in soil samples collected during borehole drilling.

Presented below are brief explanations of the methods to be used during PNNL and off-site laboratory analysis.

\subsubsection{On-Site Laboratory Analysis}

Soil samples collected during borehole drilling will be analyzed for hexavalent chromium at a PNNL laboratory on the Hanford Site utilizing a colorimetric detection system produced by the Hach Company (Hach Method 8023; Hach 1992) that is based on EPA SW-846 Method 7196 (EPA 1992). The soil samples will first be water-extracted using a microwave digestion apparatus (Thornton et al. 2000). Microwave assisted extraction can be conducted in sets of up to 12 samples. Three grams $(0.1 \mathrm{oz}$. $)$ of a soil sample will be weighed in a $125-\mathrm{ml}(4 \mathrm{oz}$.) Teflon microwave digestion vessel. Thirty mls $(1 \mathrm{oz}$.) of Milli-Q water will be added to the soil sample in the digestion vessel. The solution will be filtered and a 
Table 5.1. Phase 1 and 2 Soil Samples and Analytical and Geotechnical Methods for Site Characterization

\begin{tabular}{|c|c|c|c|c|c|c|}
\hline $\begin{array}{c}\text { Sample } \\
\text { Type }\end{array}$ & $\begin{array}{c}\text { Number of } \\
\text { Samples }\end{array}$ & Analysis & $\begin{array}{c}\text { Laboratory } \\
\text { Method }\end{array}$ & $\begin{array}{l}\text { Sample } \\
\text { Container }\end{array}$ & Preservative & $\begin{array}{l}\text { Holding } \\
\text { Time }\end{array}$ \\
\hline Soil & $\begin{array}{l}156 \text { (Includes } \\
15 \text { duplicates) }\end{array}$ & Chromium (VI) & $\begin{array}{c}\text { Hach Method } \\
8023\end{array}$ & \multirow[t]{7}{*}{$\begin{array}{c}60 \mathrm{~mL} \text { Clear } \\
\text { Wide Mouth } \\
\text { Glass Jar }\end{array}$} & None & 24 hours \\
\hline Soil & 15 & Chromium (VI) & $\begin{array}{c}\text { EPA Method } \\
7196\end{array}$ & & Cool at $4^{\circ} \mathrm{C}$ & 24 hours \\
\hline Soil & 15 & Total Metals & KLM XRF-01 & & None & 6 months \\
\hline Soil & 15 & $\begin{array}{l}\text { Total Available } \\
\text { Iron, } \\
\text { Chromium, and } \\
\text { Manganese }\end{array}$ & $\begin{array}{l}\text { Heron et al. } \\
\text { ICAP }\end{array}$ & & None & 6 months \\
\hline Soil & 15 & Ferrous Iron & $\begin{array}{c}\text { Loeppert and } \\
\text { Inskeep }\end{array}$ & & None & 6 months \\
\hline Soil & 15 & Ferric Iron & $\begin{array}{l}\text { Loeppert and } \\
\text { Inskeep }\end{array}$ & & None & 6 months \\
\hline Soil & $\overline{15}$ & TOC & Lab Specific & & Cool at $4^{\circ} \mathrm{C}$ & - \\
\hline$\overline{\text { Soil }}$ & $\overline{15}$ & $\begin{array}{l}\text { Moisture } \\
\text { Content }\end{array}$ & PNL-SA-7 & $\begin{array}{c}\text { Moisture Tin } \\
\text { and Sealing } \\
\text { Tape }\end{array}$ & None & $\begin{array}{c}2-3 \\
\text { months }\end{array}$ \\
\hline Soil & 15 & $\begin{array}{l}\text { Bulk Density } \\
\text { Sieve Analysis } \\
\text { Permeability }\end{array}$ & $\begin{array}{l}\text { PNL-SA-8 } \\
\text { PNL-SA-2 } \\
\text { PNL-SA-4 }\end{array}$ & Liner & None & None \\
\hline
\end{tabular}

portion of the sample will be analyzed using Chroma $\operatorname{Ver}^{\mathrm{TM}} 3$ powder pillows and a Hach DR/2000. spectrophotometer. The chromium (VI) concentration of the leachate samples will be converted to the chromium (VI) concentration of the soil.

Ten percent of soil samples collected during pre-test drilling will be analyzed by PNNL to determine total available iron, chromium, and manganese; ferric iron; ferrous iron; and total organic carbon content. Sediments will be treated with 0.5 molar hydrochloric acid for 24 hours to obtain total extractable iron, chromium, and manganese fractions. This extraction targets poorly crystalline ("active") iron oxides in addition to water-soluble metals. Total available iron, chromium, and manganese will be measured in these soil sample extracts by ICP (inductively coupled plasma emission spectroscopy). Total iron and ferrous iron will also be determined colorimetrically using the phenanthroline method and ferric iron obtained by difference.

Geotechnical tests will be conducted on selected soil samples by PNNL. These measurements will include the determination of sieve analysis, permeability, moisture content, bulk density, and particle density, and will be conducted in accordance with procedures PNL-SA-2, PNL-SA-4, PNL-SA-7, PNL-SA-8, and PNL-SA-9 or their equivalent (PNL-MA-567). 
Table 5.2. Post-Test Soil Samples and Analytical and Geotechnical Methods for Site Characterization

\begin{tabular}{|c|c|c|c|c|c|c|}
\hline $\begin{array}{c}\text { Sample } \\
\text { Type }\end{array}$ & $\begin{array}{l}\text { Number of } \\
\text { Samples }\end{array}$ & Analysis & $\begin{array}{l}\text { Laboratory } \\
\text { Method }\end{array}$ & $\begin{array}{c}\text { Sample } \\
\text { Container }\end{array}$ & Preservative & $\begin{array}{c}\text { Holding } \\
\text { Time }\end{array}$ \\
\hline Soil & $\begin{array}{l}45 \text { (Includes } \\
5 \text { duplicates) }\end{array}$ & $\begin{array}{l}\text { Chromium } \\
\text { (VI) }\end{array}$ & 7196 & \multirow[t]{7}{*}{$\begin{array}{c}60 \mathrm{~mL} \text { Clear } \\
\text { Wide Mouth } \\
\text { Glass Jar }\end{array}$} & \multirow[t]{7}{*}{$\begin{array}{l}\text { Cool at } 4^{\circ} \mathrm{C} \\
\text { (Ice), argon } \\
\text { atmosphere }\end{array}$} & 24 hours \\
\hline Soil & 5 & Total Metals & KLM XRF-01 & & & 6 months \\
\hline Soil & 5 & $\begin{array}{c}\text { Total } \\
\text { Available Iron } \\
\text { and Chromium }\end{array}$ & Heron et al. ICAP & & & 6 months \\
\hline Soil & 5 & Ferrous Iron & $\begin{array}{l}\text { Loeppert and } \\
\text { Inskeep }\end{array}$ & & & 6 months \\
\hline Soil & 5 & Ferric Iron & $\begin{array}{l}\text { Loeppert and } \\
\text { Inskeep }\end{array}$ & & & 6 months \\
\hline Soil & 5 & $\begin{array}{l}\text { Elemental } \\
\text { Sulfur }\end{array}$ & $\begin{array}{c}\text { Solvent } \\
\text { Extraction/UV-vis } \\
\text { Spectrophotometry }\end{array}$ & & & 6 months \\
\hline Soil & 5 & $\begin{array}{l}\text { Soluble Sulfur } \\
\text { Species }\end{array}$ & $\begin{array}{c}\text { Ion } \\
\text { Chromatography }\end{array}$ & & & 6 months \\
\hline Soil & $\overline{5}$ & $\begin{array}{c}\text { Moisture } \\
\text { Content }\end{array}$ & PNL-SA-7 & $\begin{array}{c}\text { Moisture Tin } \\
\text { and Sealing } \\
\text { Tape }\end{array}$ & None & $\begin{array}{c}2-3 \\
\text { months }\end{array}$ \\
\hline
\end{tabular}

\subsubsection{Offsite Chemical Analyses of Soil Samples}

Ten percent of the soil samples collected during borehole drilling will be sent to an offsite commercial laboratory for analysis for chromium (VI) using EPA SW-846 Method 7196. This analysis will consist of water leach extraction, as specified by PNNL, followed by analysis by the diphenylcarbazide colorimetric method, which is sensitive only to the chromium (VI) portion of the total dissolved chromium. In addition, $10 \%$ of soil samples collected during borehole installation will be analyzed for major, minor and trace element constituents including aluminum, calcium, total iron, total chromium, potassium, silicon, sulfur, and other metals and cations using energy dispersive X-Ray fluorescence. 


\subsection{Data Quality Objectives}

The primary objective of the demonstration test is to evaluate the feasibility of the ISGR technology by applying it to the treatment of chromium in the unsaturated zone of the field test site. The results will be used to evaluate the potential application of the technology at other sites for immobilizing chromium and determining the cost of the technology relative to other approaches.

As indicated in a draft treatability test plan, ${ }^{(a)}$ data collection during the demonstration will be focused on:

- determining the system's effectiveness for immobilizing and detoxifying hexavalent chromium in the unsaturated zone

- optimizing equipment operation

- assessing the potential impacts of the technology to the environment

- determining the cost effectiveness of the technology.

Identification of the type and amount of data to be collected and the methods used to collect and analyze the sample data for this drilling work plan were directed by the Data Quality Objectives (DQO) process. This process involves a series of planning steps based on the scientific method that are designed to ensure that the type, quantity, and quality of environmental data used in decision making are appropriate for the intended application. Specific data needs that will be fulfilled as a result of implementing this drilling plan include the following:

- distribution and concentrations of chromium (VI) in the soil

- test site physical properties

- contaminant reduction in the sediments

- impact of the process on the vadose zone

- analytical data required for waste designation.

(a) Thornton, E. C., K. B. Olsen, T. J Gilmore, R. Schalla, K. Cantrell, S.W. Petersen, and M. Oostrom. 2000. Treatability Test Plan for In Situ Gaseous Reduction at the Hanford 183-DR Site. Pacific Northwest National Laboratory, Richland, Washington. 
Of greatest importance is the concentration and distribution of chromium (VI) in the wellfield network before and after gas treatment. Table 6.1 presents the analytical methods, quantitation limits, and precision and accuracy guidelines associated with determination of hexavalent and total chromium present in the soils by PNNL. Since samples will be analyzed by an offsite laboratory using EPA methods and protocols, their quality control methodology is acceptable and is not discussed further. Analytical data needs are presented in Tables 5.1 and 5.2 that support site characterization activities and evaluation of demonstration effectiveness in the reduction and immobilization of chromium (VI).

The analytical requirements associated with waste designation are summarized in Attachment 1 (183-DR ISGR Drilling Waste DQO Summary Report). Drilling waste management is discussed in Section 9 and analytical data needs are presented in Table 6.2 of this document.

Table 6.1. Chromium Analytical Methods, Quantitation Limits and Precision and Accuracy Guidelines

\begin{tabular}{|l|c|c|c|c|}
\hline \multicolumn{1}{|c|}{ Analyte } & $\begin{array}{c}\text { Analytical } \\
\text { Method }\end{array}$ & $\begin{array}{c}\text { Practical Quantitation }_{\text {Limit Soil }^{(\mathbf{a})}} \\
\text { Hexavalent Chromium }\end{array} 7^{\left(196^{(\mathrm{c})}\right.}$ & $\begin{array}{c}\text { Precision }^{(\mathbf{b})} \\
\text { (RPD) }\end{array}$ & Accuracy $^{(\mathbf{b})}$ \\
\hline Total Chromium & KLM XRF-01 & $2 \mathrm{mg} / \mathrm{kg}$ & \pm 20 & $75-125$ \\
\hline
\end{tabular}

(a) Values are to be considered requirements in the absence of known or suspected analytical interferences that may hinder achieving the limit by the analytical laboratory.

(b) Precision is expressed as relative percent difference; accuracy is expressed as percent recovery. These limits apply to sample results greater than five times the target quantitation limit and are to be considered requirements in the absence of known or suspected analytical interferences that may hinder achieving the limit by the analytical laboratory.

(c) Methods specified are EPA (1992) or equivalent. 
Table 6.2. Analytical Methods for Waste Designation

\begin{tabular}{|l|c|c|c|c||}
\hline \multicolumn{1}{|c|}{ Sample Type } & $\begin{array}{c}\text { Number of } \\
\text { Samples }\end{array}$ & Analysis & Laboratory & Laboratory Method \\
\hline Borehole Sediments & 12 & NA & STL & TCLP Leaching \\
\hline TCLP Leachate & 12 & Metals & STL & EPA Method 6010 \\
\hline TCLP Leachate & 12 & Mercury & STL & EPA Method 7470 \\
\hline TCLP Leachate & 12 & Volatile Organics & STL & EPA Method 8260 \\
\hline Borehole Sediments & 156 & Chromium (VI) & PNNL & Hach Method 8023 \\
\hline Borehole Sediments & 141 & pH & PNNL & Electrometric \\
\hline Borehole Sediments & 15 & Chromium (VI) & STL & EPA Method 7196 \\
\hline Borehole Sediments & 15 & Total Metals & KLM & KLM XRF-01 \\
\hline Borehole Sediments & 4 & Soil VOA & PNNL & PNL Method VOA-3 \\
\hline Borehole Sediments & 12 & Alpha, Beta, and Gamma & STL & STL-RC-5020 \\
\hline Borehole Sediments & 12 & PCBs & PNNL & EPA Method 4020 \\
\hline \hline Groundwater & 1 & Alpha, Beta, and Gamma & STL & STL-RC-5014 \\
\hline Groundwater & 1 & Anions & PNNL & EPA Method 300.1 \\
\hline Groundwater & 1 & Metals & STL & EPA Method 6010 \\
\hline Groundwater & 1 & VOA & PNNL & PNL Method VOA-3 \\
\hline Groundwater & 1 & Chromium (VI) & STL & EPA Method 7196 \\
\hline $\begin{array}{l}\text { STL = Steven Trent Laboratory (Quanterra), Richland, WA. } \\
\text { KLM = KLM Analytical Laboratory, Richland, WA. }\end{array}$ \\
PNNL = Pacific Northwest National Laboratory, Richland, WA. & & \\
\hline
\end{tabular}




\subsection{Quality Assurance}

All work conducted by PNNL shall be performed according to appropriate standards of quality, reliability, environmental compliance, and safety based on client requirements, cost and program objectives, and potential consequences or malfunction or error. To provide clients with quality products and services, PNNL has established and implemented a formal Quality Assurance (QA) Program. These management controls are documented in the PNNL Standard Based Management System (SBMS) and its accompanying standards and procedures. DOE Orders 414.1 and 10 CFR 830.120 as delineated in SBMS, will be applied along with supplementing approaches from ANSI/ASQC E-4 (1994), Specifications and Guidelines for Quality Systems for Environmental Data Collection and Environmental Technology Programs.

The data collection activities associated with this description of work are discussed in Sections 5, 6, and 9. In particular, collection and analysis of soil samples is an important aspect of site characterization, evaluation of the effectiveness of the ISGR demonstration, and for drilling waste designation. The analytical methods and sampling information that address these objectives are summarized in Tables 5.1, $5.2,6.1$, and 6.2. A minimum of one duplicate soil sample shall also be collected for analysis each day samples are collected. The purpose of collecting duplicate samples is to assess and document overall analytical precision. Duplicate samples will be collected for approximately $10 \%$ of all soil samples to be sent to an offsite commercial laboratory. 


\subsection{Sample Documentation and Custody}

Sample collection and analysis and chain-of-custody will be documented in accordance with the following sections. All pertinent records generated in the field or laboratory will be transferred to PNNL for storage in the project file.

\subsection{Field Documentation}

Sampling team members are responsible for properly documenting sample collecting activities in accordance with procedures PNL-DO-4, PNL-AD-4, and PNL-SA-1 (PNL 1993) or their equivalents to provide an accurate and defensible record of sample collection for each sample. Specific sample collection information shall be recorded on the appropriate field record sheets. Supplemental sampling information (as required in the sampling procedure) shall be recorded in a field logbook. In addition, field geologist will record in field log those samples that will analyzed for waste designation as well as all screening results on the borehole log.

\subsection{Photographs}

Photographs will be taken throughout all aspects of characterization and process monitoring activities. A record of these photographs (by roll and frame number [e.g., R1/F3]) will be kept in the field log book.

\subsection{Sample Numbering System}

Every sample collected, including soil and effluent, is assigned a unique sample identification number. For soil, a suffix indicating the depth (in feet) at which the sample was taken is part of the identification number. For example, a sample collected at a designated location is assigned sample identification number $183 \mathrm{DR}-\mathrm{BH}$; for samples collected at depths of 10,20 , and $30 \mathrm{ft}$ at this location, the complete sample identification numbers would be: 183DR-BH1-10, 183DR-BH1-20, and 183DRBH1-30, respectively.

\subsection{Laboratory Documentation}

Laboratory documentation should include the following, as appropriate:

- instrument calibration records

- instrument tuning records

- method blank records

- calibration verification records

- documentation of standards traceability

- sample records, including sample ID number, date, and time of analysis

- equipment blank records 
- QC sample analysis records

- date of standard preparation or sample collection

- date and time of standard or sample analysis

- printed name and signature of analyst.

Computer-generated hard copies of pertinent analytical runs shall be prepared. Additional information shall be recorded in a laboratory notebook. Prenumbered, dated forms and computersoftware-generated records of tuning calibration, standard and sample analyses, qualitative and quantitative routines, and laboratory notebooks may be used to record information.

\subsection{Chain-of-Custody}

In order to document the integrity of samples from collection to analysis, sample possession will be recorded on an Analysis Request and Chain of Custody Form per PNL-AD-4 (PNL 1993) or its equivalent. A sample is considered to be in a person's custody if it is in his/her physical possession, in view after being in physical possession, secured by him/her so that no one can tamper with the sample or tampering is easily detected or in a secured area that is restricted to authorized personnel. Analysis Request and Chain of Custody Forms will be prepared for all samples collected for laboratory analyses. The Analysis Request and Sample Request Form will include the following: sample team members, sample numbers, required analytical testing, number and type of containers, date and time of sample collection, shipping carrier and waybill number and dated signatures of individuals relinquishing and receiving samples into custody. This form is to be initiated at the point of sample collection and it will be kept with the samples during transfer to the laboratory. The form will be completed upon receipt at the laboratory. 


\subsection{Waste Management}

This section summarizes the management of waste generated during well drilling and construction associated with the ISGR Treatability Study. Any wastes generated during the 183-DR treatability test drilling will be managed in accordance with the Interim Action Waste Management Plan for the 100-HR-3 and 100-KR-4 Operable Units, as amended (DOE 2000). This document meets the intent of the Strategy for Management of Investigation Derived Waste (DOE 1999) and serves as the Waste Control Plan for the 183-DR drilling activities. Site Specific Waste Management Instructions will be developed for drilling activities. If drilling is successful and the treatability test moves forward, a separate waste control plan would be developed due to the unique nature of the wastes that may be generated.

Expected well drilling and construction waste streams include the following:

- drill cuttings (both dry and saturated)

- purgewater generated during well development and monitoring

- purgewater generated during decanting of soils and slurries

- decontamination fluids

- liquids generated during screening analysis

- miscellaneous solid waste such as bentonite, sand, wipes, gloves and other personnel protective equipment, cloth, sampling and measuring equipment, pumps, pipe, wire, plastic sheeting, tools, or materials generated from cleanup of spills.

The wastes generated during drilling will be contained at the drill site, and will be managed as set forth in the waste management plan (DOE 2000).

Waste will be designated using process knowledge and analytical data. Analysis of specific constituents for waste designation have been determined using the data quality objectives process The DQO waste designation summary report for the 183-DR drilling activities identifies the constituents of concern and the sample/measurement design to ensure proper disposition of wastes (Attachment 1, Tables 1-13 and 1-16). Waste will be designated with standard EPA laboratory methods as listed in Table 6.2. 


\subsection{Schedule}

Drilling operations associated with the first two exploration boreholes are scheduled to begin in early July 2000. If sufficient concentrations of hexavalent chromium are observed in borehole sediment samples, drilling of the extraction wells will begin in mid-July and continue through September 2000. Drilling of post-test boreholes will occur after completion of ISGR treatment at the site, during mid to late fiscal year 2001. 


\subsection{General Requirements}

General worker health and safety training requirements, technical procedures, and technical specifications associated with this drilling project are identified in the following sections.

\subsection{Safety and Health}

All personnel working at the drilling sites under this description of work will have completed, at a minimum, an Occupational Safety and Health Administration Act 40-hour Hazardous Waste Site Worker training program (29 CFR 1910.120). The drilling will be performed in accordance with requirements in the subcontractor's Health and Safety Plan and Activity Hazard Analysis.

\subsection{Technical Procedures/Specifications}

This section identifies technical procedures/specifications applicable to field activities performed under this description of work. Activities associated with installing the boreholes will adhere to the following documents:

- PNNL Field Procedures (in PNL-MA-567)

- QC-02 Collection and Handling of Quality Control Samples

- AD-04 Sediment Sample Chain-of-Custody and Field Record Form

- DO-01 Collection and Documentation of Borehole Samples and Well Construction Data

- DO-04 Contaminated Sediment Sampling

- AD-04 Sediment Sample Chain-of-Custody and Field Record Form

- PNNL Geotechnical Procedures (in PNL-MA-567)

- SA-1 Sediment Sample Analysis/Sample Control Procedure

- SA-2 Sieve Procedure

- SA-4 Constant Head Hydraulic Conductivity Determination Procedure

- SA-7 Water Content

- SA-8 Clod Density/Bulk Density

- SA-9 Determining Particle Density

- XRF Method (KLM XRF-01)

- Project Specific Procedures

- Water-Extraction of Chromium (VI) from Soil Samples (Section 5.1.1) 
- BHI Waste Management Plan (BHI-EE-10)

- Field Support Administration (BHI-FS-01)

- PNNL Quality Assurance Program (SBMS) 


\subsection{References}

10 CFR 830.120. 1994. “Quality Assurance Requirements.” Code of Federal Regulations.

29 CFR 1910.120. "Hazardous Waste Operations and Emergency Response." Code of Federal Regulations, as amended.

ANSI/ASQC E-4. 1994. Specifications and Guidelines for Quality Systems for Environmental Data Collection and Environmental Technology Programs. American Society for Quality Control, Milwaukee, Wisconsin.

BHI-EE-10. Waste Management Plan. Bechtel Hanford, Inc., Richland, Washington.

BHI-FS-01. Field Support Administration. Bechtel Hanford, Inc., Richland, Washington.

Hach. 1992. DR/2000 Spectrophotometer Procedures Manual. Hach Company, Loveland, Colorado.

Heron, G., C. Crouzet, A.C.M. Bourg, and T. H. Christensen. 1994. "Speciation of Fe(II) and Fe(III) in Contaminated Aquifer Sediments Using Chemical Extraction Techniques." Environ. Sci. Technol., 28, 1698-1705.

KLM Analytical Laboratory (KLM). 2000. Energy Dispersive X-Ray Fluorescence Spectroscopy Using the BFP Approach with the Kevex 0810A System. KLM Procedure XRF-01 (PNL-AL0-266). KLM Analytical Laboratory, Richland, Washington.

Loeppert, R. L., and W. P. Inskeep. 1996. "Iron." In Methods of Soil Analysis, Part 3 Chemical Methods, Chapter 23, Iron, ed. D. L. Sparks, pp. 639-664. Soil Sci. Soc. Am., Madison, Wisconsin.

Pacific Northwest Laboratory (PNL). 1993. Procedures for Groundwater Investigations. PNL-MA-567, Rev. 1, Pacific Northwest Laboratory, Richland, Washington.

Richards, R. B. 1953. Process Specifications Reactor Cooling Water Treatment. HW-28505, General Electric, Richland, Washington.

Rohay, V. J., D. C. Weekes, W. J. McMahon, and J. V. Borghese. 1999. The Chromium Groundwater Plume West of the 100-D/DR Reactors: Summary and Fiscal Year 1999 Update. BHI-01309, Rev. 0, Bechtel Hanford, Inc., Richland, Washington.

Thornton, E. C., J. T. Giblin, T. J Gilmore, K. B. Olsen, J. M. Phelan, and R. D. Miller. 1999. In Situ Gaseous Reduction Pilot Demonstration - Final Report. PNNL-12121, Pacific Northwest National Laboratory, Richland, Washington. 
Thornton, E. C., K. J. Cantrell, J. M. Faurote, T. J. Gilmore, K. B. Olsen, and R. Schalla. 2000. Identification of a Hanford Waste Site for Initial Deployment of the In Situ Gaseous Reduction Approach. PNNL-13107, Pacific Northwest National Laboratory, Richland, Washington.

U.S. Department of Energy (DOE). 1999. Environmental Restoration Program Strategy for Management of Investigation Derived Waste (Letter No. 067483, to D. R. Sherwood, U.S. Environmental Protection Agency, and M. A. Wilson, Washington State Department of Ecology, March 29, 1999), U.S. Department of Energy, Richland Operations Office, Richland, Washington.

U.S. Department of Energy (DOE). 2000. Interim Action Waste Management Plan for the 100-HR-3 and 100-KR-4 Operable Units, Rev. 2. U.S. Department of Energy, Richland Operations Office, Richland, Washington.

U.S. Department of Energy (DOE) Order 414.1. 1998. Quality Assurance. Washington, D.C.

U.S. Environmental Protection Agency (EPA). 1992. Test Methods for Evaluating Solid Waste Physical/Chemical Methods, $3^{\text {rd }}$ ed. SW-846. U.S. Environmental Protection Agency, Washington, D.C.

Westinghouse Hanford Company (WHC). 1993. 100-D Area Technical Baseline Report. WHC-SD-ENTI-181, Rev. 0, Westinghouse Hanford Company, Richland, Washington. 


\title{
Attachment 1
}

\section{3-DR ISGR Drilling Waste Designation DQO Summary Report}

\author{
Prepared by
}

Bechtel Hanford Inc.

May 2000 


\subsection{EXISTING REFERENCES}

Table 1-1 presents a list of all of the references that were reviewed as part of the scoping process and a summary of the pertinent information contained within each reference.

Table 1-1. Existing References. (2 pages)

\begin{tabular}{|c|c|}
\hline Reference & Summary \\
\hline $\begin{array}{l}\text { 100-D Area Technical Baseline Report, } \\
\text { WHC-SD-EN-TI-181 (WHC 1993) }\end{array}$ & $\begin{array}{l}\text { Page 2-5 presents a figure and text that address a typical water } \\
\text { treatment system and the processes that occurred at a water } \\
\text { treatment plant such as } 183-\mathrm{DR} \text {. Page } 4-69 \text { notes that the } 183-\mathrm{D} \\
\text { Facility (i.e., filter plant, head house, chemical building, basins, } \\
\text { filter building, and clearwells) provided sanitary water to the } \\
100-\mathrm{F}, 100-\mathrm{H} \text {, and } 100-\mathrm{D} \text { Areas. Large sulfuric acid storage tanks } \\
\text { located to the southwest of the facility have been removed. } \\
\text { Beneath the acid tanks is a small concrete trench drainage system. } \\
\text { Equipment and concrete show corrosion. A filter backwash valve } \\
\text { was surveyed in } 1964 \text { and showed no detectable radiological } \\
\text { contamination; however, Table } 5-8 \text { lists } 183-\mathrm{DR} \text { as a facility that } \\
\text { has the potential for hazardous or radioactive contamination. }\end{array}$ \\
\hline $\begin{array}{l}\text { Design and Construction History, } \\
\text { Project C-342, 100-DR Water Plant } \\
\text { (GE 1952) }\end{array}$ & $\begin{array}{l}\text { Page } 18 \text { indicates that the water filter plant includes filter } \\
\text { equipment, clearwell depth gauges, washwater rate-of-flow } \\
\text { controllers, raw water meters, basin valves and gates, mechanical } \\
\text { mixing equipment, flocculating equipment, chemical feeding } \\
\text { equipment, chlorinating apparatus, and pH recording equipment. } \\
\text { Attached to head house are two dry chemical storage silos and two } \\
\text { dry chemical conveyor systems. Contains six sedimentation and } \\
\text { flocculating basins, three flocculators, and three drywells. }\end{array}$ \\
\hline $\begin{array}{l}\text { 100-D/DR Reactor Area Pipeline } \\
\text { Evaluations, (no document number) } \\
\text { (BHI 1999) }\end{array}$ & $\begin{array}{l}\text { Six pipelines were associated with the } 183-\mathrm{DR} \text { head house and } \\
\text { carried sodium dichromate and raw water. Five pipelines were } \\
\text { associated with the 183-DR Filter Building and carried sewage and } \\
\text { fresh water. }\end{array}$ \\
\hline $\begin{array}{l}\text { Identification of a Hanford Waste Site } \\
\text { for Initial Deployment of the In Situ } \\
\text { Gaseous Reduction Approach, PNNL- } \\
13107 \text { (Thornton et al. 2000) }\end{array}$ & $\begin{array}{l}\text { The 183-DR appears to be the source of a local hexavalent } \\
\text { chromium groundwater plume. Chromate was known to have been } \\
\text { stored at the facility as a corrosion inhibitor. The chromate was } \\
\text { contained in storage tanks. Soil shows reddish-orange } \\
\text { discoloration to depth of } 0.9 \mathrm{~m} \text { ( } 3 \mathrm{ft} \text { ). Fifty soil samples were } \\
\text { collected during excavation of trenches and pits and were analyzed } \\
\text { by Pacific Northwest National Laboratory for hexavalent } \\
\text { chromium, but no significant contamination was detected. A set of } \\
10 \text { of the excavated samples were analyzed for metals using x-ray } \\
\text { fluorescence. One sample showed total chromium concentrations } \\
\text { of } 650 \text { parts per million (ppm) and was enriched in lead. }\end{array}$ \\
\hline
\end{tabular}


Table 1-1. Existing References. (2 pages)

\begin{tabular}{|l|l|}
\hline \multicolumn{1}{|c|}{ Reference } & \multicolumn{1}{c|}{ Summary } \\
\hline Process Specifications Reactor Cooling & $\begin{array}{l}\text { Aluminum sulfate shall be added continuously to the raw water } \\
\text { inlet of the head house as required to maintain the process water } \\
\text { quality so a significant increase in film formation rate will not take } \\
\text { place in the reactor process tubes. Ferric sulfate will be added } \\
\text { continuously at the raw water inlets of the 183-B and 183-H head } \\
\text { house. Page 9-1 states that no other materials shall be added to } \\
\text { reactor process water except ferric sulfate, aluminum sulfate, } \\
\text { sodium silicate, sulfuric acid, chlorine, lime, sodium dichromate, } \\
\text { and diatomaceous earth. }\end{array}$ \\
\hline
\end{tabular}

\subsection{TOTAL LIST OF CONTAMINANTS OF POTENTIAL CONCERN}

Table 1-2 identifies all of the contaminants of potential concern (COPCs) for each of the waste streams expected to be generated within each functional area of the facility. The waste streams are numbered for tracking purposes; these waste stream numbers do not represent waste code numbers.

Table 1-2. Total List of COPCs for Each Waste Stream.

\begin{tabular}{|c|l|l|l|l|}
\hline $\begin{array}{c}\text { WS } \\
\#\end{array}$ & Waste Stream & $\begin{array}{c}\text { Known or Suspected } \\
\text { Source of Contamination }\end{array}$ & $\begin{array}{c}\text { Type of } \\
\text { Contamination } \\
\text { (General) }\end{array}$ & \multicolumn{1}{c|}{$\begin{array}{c}\text { COPCs } \\
\text { (Specific) }\end{array}$} \\
\hline 1 & $\begin{array}{l}\text { Soil cuttings from the } \\
\text { drilling of two wells } \\
\text { in vicinity of 183-DR } \\
\text { Water Treatment Plant }\end{array}$ & $\begin{array}{l}\text { Leaking underground } \\
\text { transfer lines }\end{array}$ & $\begin{array}{l}\text { Chemicals to } \\
\text { reduce film } \\
\text { formation, reduce } \\
\text { filter breakthrough, } \\
\text { and inhibit } \\
\text { corrosion }\end{array}$ & $\begin{array}{l}\text { Aluminum sulfate, ferric } \\
\text { sulfate, sulfuric acid } \\
\text { (pH), sodium silicate, } \\
\text { alum, chlorine, hydrated } \\
\text { calcium oxide lime, } \\
\text { diatomaceous earth, } \\
\text { sodium dichromate } \\
\left(\text { Cr }{ }^{+6} \text { ), metals, }\right. \\
\text { radionuclides, } \\
\text { polychlorinated biphenyls }\end{array}$ \\
\hline
\end{tabular}

\subsection{CONTAMINANT OF POTENTIAL CONCERN EXCLUSIONS}

Table 1-3 presents a list of all other COPCs to be excluded from the investigation. These exclusions are based on physical laws, process knowledge, task focus, or other mitigating factors. Table 1-3 also provides the specific rationale for the exclusion of each of the identified COPCs. 
Table 1-3. Rationale for COPC Exclusions.

\begin{tabular}{|l|l|l|}
\hline WS \# & \multicolumn{1}{|c|}{ COPCs } & \multicolumn{1}{c|}{ Rationale for Exclusion } \\
\hline \multirow{5}{*}{} & Sodium silicate & Non-toxic \\
\cline { 2 - 3 } & Alum & Non-toxic \\
\cline { 2 - 3 } & Chlorine & Reactive species; dissipated after 30 years \\
\cline { 2 - 3 } & Hydrated calcium oxide & Non-toxic \\
\cline { 2 - 3 } & Lime & Non-toxic \\
\cline { 2 - 3 } & Diatomaceous earth & Non-toxic \\
\hline
\end{tabular}

$\mathrm{TBD}=$ to be determined

\subsection{FINAL LIST OF CONTAMINANTS OF CONCERN}

Table 1-4 presents the final list of contaminants of concern (COCs) for each waste stream number to be carried through the remainder of the DQO process.

Table 1-4. Final List of COCs.

\begin{tabular}{l|l|}
\hline WS \# & COCs \\
\hline 1 & Radionuclides $^{\mathrm{a}}$, metals, polychlorinated biphenyls ${ }^{\mathrm{b}}$, sulfate, $\mathrm{pH}$ \\
\hline a & $\begin{array}{l}\text { While no sources of radionuclides are reported at the site, they have been included because sources are present in area } \\
\text { surrounding the site. }\end{array}$ \\
b & $\begin{array}{l}\text { Polychlorinated biphenyls may have been present in one or more transformers present at the site. Although } \\
\text { polychlorinated biphenyls are not expected to be present in the soils, they have been included for verification purposes. }\end{array}$
\end{tabular}

\subsection{CONCEPTUAL SITE MODEL}

The goal of the DQO process is to develop a sampling design that will either confirm or reject the conceptual site model. The conceptual site model is continuously being refined as additional data become available. Table $1-5$ presents a tabular depiction of the conceptual site model, identifying the sources, release mechanisms, migration pathways, and potential receptors for each of the COCs. This table also summarizes the exposure scenarios. 
Table 1-5. Tabular Depiction of the Conceptual Site Model.

\begin{tabular}{|c|c|c|c|c|c|}
\hline $\begin{array}{c}\text { WS } \\
\#\end{array}$ & COCs & Source & $\begin{array}{c}\text { Release } \\
\text { Mechanism }\end{array}$ & Migration Pathways & Potential Receptors \\
\hline 1 & $\begin{array}{l}\text { Radionuclides, } \\
\text { metals, } \\
\text { polychlorinated } \\
\text { biphenyls, } \\
\text { sulfate, pH }\end{array}$ & $\begin{array}{l}\text { Drums containing } \\
\text { drill cuttings from } \\
\text { boreholes drilled in } \\
\text { the vicinity of } \\
\text { 183-DR Water } \\
\text { Treatment Plant }\end{array}$ & $\begin{array}{l}\text { Leaking } \\
\text { drums }\end{array}$ & $\begin{array}{l}\text { Dependant upon } \\
\text { disposal option } \\
\text { selected. If disposed } \\
\text { in a lined landfill, } \\
\text { there are no } \\
\text { pathways for } \\
\text { migration. } \\
\text { Otherwise, surface } \\
\text { water and } \\
\text { groundwater are } \\
\text { potential pathways. }\end{array}$ & $\begin{array}{l}\text { Dependant upon } \\
\text { disposal option. If } \\
\text { disposed in a lined } \\
\text { landfill, there are no } \\
\text { receptors. } \\
\text { Otherwise, receptors } \\
\text { may include fish in } \\
\text { the Columbia River, } \\
\text { and human and } \\
\text { ecological } \\
\text { populations in the } \\
\text { vicinity of the } \\
\text { drums. }\end{array}$ \\
\hline
\end{tabular}

\subsection{STATEMENT OF THE PROBLEM}

The problem is that approximately. 64 drums of soil cuttings will be generated as a result of the drilling of eight groundwater monitoring wells in the vicinity of the 183-DR Water Treatment Plant. The drums need to be characterized for purposed waste disposal.

\subsection{IDENTIFY THE DECISION}

Table 1-6 presents the task-specific principal study questions (PSQs), alternative actions (AAs), and resulting decision statements. The table also provides a qualitative assessment of the severity of the consequences of taking an alternative action if it is incorrect. This assessment takes into consideration human health and environment (i.e., flora/fauna) and political, economic, and legal ramifications. The severity of the consequences is expressed as low, moderate, or severe. 
Table 1-6. Summary of DQO Step 2 Information. (4 pages)

\begin{tabular}{|c|c|c|c|}
\hline $\begin{array}{l}\text { PSQ- } \\
\text { AA\# } \#\end{array}$ & Alternative Action & $\begin{array}{c}\text { Description of Consequences } \\
\text { of Implementing the Wrong } \\
\text { Alternative Action } \\
\end{array}$ & $\begin{array}{l}\text { Severity of Consequences } \\
\text { (Low/Moderate/Severe) }\end{array}$ \\
\hline \multicolumn{4}{|c|}{ Principal Study Question \#1 - Is the material radiologically contaminated? } \\
\hline $1-1$ & $\begin{array}{l}\text { The material is not radiologically } \\
\text { contaminated and will be considered } \\
\text { for offsite recycling/reuse or clean } \\
\text { landfill disposition. }\end{array}$ & $\begin{array}{l}\text { Public may be exposed to } \\
\text { radiological contamination. }\end{array}$ & Severe \\
\hline $1-2$ & $\begin{array}{l}\text { The material is radiologically } \\
\text { contaminated and will be evaluated for } \\
\text { onsite disposal. }\end{array}$ & $\begin{array}{l}\text { Unnecessary cost of treating } \\
\text { clean material as if it were } \\
\text { contaminated. }\end{array}$ & Low to moderate \\
\hline $1-3$ & No action. & $\begin{array}{l}\text { Public or workers may be } \\
\text { exposed to radiological } \\
\text { contamination. }\end{array}$ & Severe \\
\hline \multicolumn{4}{|c|}{ Decision Statement \#1 - } \\
\hline \multicolumn{4}{|c|}{$\begin{array}{l}\text { Determine if the potentially contaminated materials meet the radiological contamination release limits and will } \\
\text { be considered further for offsite recycling/reuse or clean landfill disposition. }\end{array}$} \\
\hline \multicolumn{4}{|c|}{$\begin{array}{l}\text { Determine if the potentially volumetrically contaminated materials meet the radiological contamination release } \\
\text { limits and will be considered further for offsite recycling/reuse or clean landfill disposition. }\end{array}$} \\
\hline \multicolumn{4}{|c|}{ Principal Study Question \#2a - Is the material a listed dangerous waste? } \\
\hline $2-1$ & $\begin{array}{l}\text { The material is a listed dangerous } \\
\text { waste and receives a listed waste code. }\end{array}$ & $\begin{array}{l}\text { Unnecessary cost of treating } \\
\text { clean material as if it were } \\
\text { contaminated. }\end{array}$ & Low to moderate \\
\hline $2-2$ & $\begin{array}{l}\text { The material is not a listed dangerous } \\
\text { waste and is not regulated as such. }\end{array}$ & $\begin{array}{l}\text { Public may be exposed to } \\
\text { dangerous waste. }\end{array}$ & Severe \\
\hline \multicolumn{4}{|c|}{ Decision Statement \#2a - Determine if the material is regulated as listed dangerous waste. } \\
\hline \multicolumn{4}{|c|}{$\begin{array}{l}\text { Principal Study Question \#2b - Is the material a characteristic waste (e.g., ignitable, corrosive, reactive, or } \\
\text { toxic)? }\end{array}$} \\
\hline $2-3$ & $\begin{array}{l}\text { The material is a characteristic waste } \\
\text { (e.g., corrosive, ignitable, reactive, } \\
\text { and/or toxic) and receives a } \\
\text { characteristic waste code. }\end{array}$ & $\begin{array}{l}\text { Unnecessary cost of treating } \\
\text { clean material as if it were } \\
\text { contaminated. }\end{array}$ & Low to moderate \\
\hline $2-4$ & $\begin{array}{l}\text { The material is not a characteristic } \\
\text { waste (e.g., corrosive, ignitable, } \\
\text { reactive, and/or toxic) and is not } \\
\text { regulated as such. }\end{array}$ & $\begin{array}{l}\text { Public may be exposed to } \\
\text { characteristic waste. }\end{array}$ & Severe \\
\hline
\end{tabular}


Table 1-6. Summary of DQO Step 2 Information. (4 pages)

\begin{tabular}{|c|c|c|c|}
\hline $\begin{array}{l}\text { PSQ- } \\
\text { AA \# }\end{array}$ & Alternative Action & $\begin{array}{c}\text { Description of Consequences } \\
\text { of Implementing the Wrong } \\
\text { Alternative Action }\end{array}$ & $\begin{array}{l}\text { Severity of Consequences } \\
\text { (Low/Moderate/Severe) }\end{array}$ \\
\hline \multicolumn{4}{|c|}{ Principal Study Question \#2c - Is the material a toxic dangerous waste per Washington State criteria? } \\
\hline $2-5$ & $\begin{array}{l}\text { The material is a toxic dangerous } \\
\text { waste per Washington State criteria } \\
\text { and receives a toxic dangerous waste } \\
\text { code. }\end{array}$ & $\begin{array}{l}\text { Unnecessary cost of treating } \\
\text { clean material as if it were } \\
\text { contaminated. }\end{array}$ & Low to moderate \\
\hline $2-6$ & $\begin{array}{l}\text { The material is not a toxic dangerous } \\
\text { waste per Washington State criteria } \\
\text { and is not regulated as such. }\end{array}$ & $\begin{array}{l}\text { Public may be exposed to } \\
\text { toxic waste. }\end{array}$ & Severe \\
\hline \multicolumn{4}{|c|}{$\begin{array}{l}\text { Decision Statement \#2c - Determine if the material meets the definition of a toxic dangerous waste per } \\
\text { Washington State criteria. }\end{array}$} \\
\hline \multicolumn{4}{|c|}{ Principal Study Question \#2d - Is the material a persistent waste per Washington State criteria? } \\
\hline $2-7$ & $\begin{array}{l}\text { The material meets the definition of a } \\
\text { persistent waste per Washington State } \\
\text { criteria. }\end{array}$ & $\begin{array}{l}\text { Unnecessary cost of treating } \\
\text { clean material as if it were } \\
\text { contaminated. }\end{array}$ & Low to moderate \\
\hline $2-8$ & $\begin{array}{l}\text { The material does not meet the } \\
\text { definition of a persistent waste per } \\
\text { Washington State criteria. }\end{array}$ & $\begin{array}{l}\text { Public may be exposed to } \\
\text { persistent waste. }\end{array}$ & Severe \\
\hline \multicolumn{4}{|c|}{$\begin{array}{l}\text { Decision Statement \#2d - Determine if the material meets the definition of a persistent waste per Washington } \\
\text { State criteria. }\end{array}$} \\
\hline \multicolumn{4}{|c|}{ Principal Study Question \#2e - Is the material a polychlorinated biphenyl waste? } \\
\hline $2-9$ & $\begin{array}{l}\text { The material is regulated due to } \\
\text { polychlorinated biphenyl } \\
\text { concentrations. }\end{array}$ & $\begin{array}{l}\text { Unnecessary cost of treating } \\
\text { clean material as if it were } \\
\text { contaminated. }\end{array}$ & Low to moderate \\
\hline $2-10$ & $\begin{array}{l}\text { The material is not regulated due to } \\
\text { polychlorinated biphenyl } \\
\text { concentrations. }\end{array}$ & $\begin{array}{l}\text { Public may be exposed to } \\
\text { polychlorinated biphenyl } \\
\text { waste. }\end{array}$ & Severe \\
\hline \multicolumn{4}{|c|}{$\begin{array}{l}\text { Decision Statement \#2e - Determine if the material is regulated due to polychlorinated biphenyl } \\
\text { concentrations. }\end{array}$} \\
\hline \multicolumn{4}{|c|}{ Principal Study Question \#2f - Is the material asbestos-containing material? } \\
\hline $2-11$ & $\begin{array}{l}\text { The material is regulated due to } \\
\text { asbestos content. }\end{array}$ & $\begin{array}{l}\text { Unnecessary cost of treating } \\
\text { clean material as if it were } \\
\text { contaminated. }\end{array}$ & Low to moderate \\
\hline $2-12$ & $\begin{array}{l}\text { The material is not regulated due to } \\
\text { asbestos content. }\end{array}$ & $\begin{array}{l}\text { Public may be exposed to } \\
\text { asbestos waste. }\end{array}$ & Severe \\
\hline $2-13$ & No action. & $\begin{array}{l}\text { Public may be exposed to } \\
\text { asbestos waste. }\end{array}$ & Severe \\
\hline \multicolumn{4}{|c|}{ Decision Statement \#2f - Determine if the material is regulated due to asbestos content. } \\
\hline \multicolumn{4}{|c|}{$\begin{array}{l}\text { Principal Study Question \#3 - Does the material radiological activity exceed the disposal facility waste } \\
\text { acceptance criteria limits? }\end{array}$} \\
\hline
\end{tabular}


Table 1-6. Summary of DQO Step 2 Information. (4 pages)

\begin{tabular}{|c|c|c|c|}
\hline $\begin{array}{l}\text { PSQ- } \\
\text { AA \# }\end{array}$ & Alternative Action & $\begin{array}{c}\text { Description of Consequences } \\
\text { of Implementing the Wrong } \\
\text { Alternative Action }\end{array}$ & $\begin{array}{l}\text { Severity of Consequences } \\
\text { (Low/Moderate/Severe) }\end{array}$ \\
\hline $3-1$ & $\begin{array}{l}\text { The radiological activity of the } \\
\text { material exceeds the disposal facility } \\
\text { waste acceptance criteria limits. It } \\
\text { will be evaluated for chemical waste } \\
\text { designation and disposition will be } \\
\text { negotiated with the regulators. }\end{array}$ & $\begin{array}{l}\text { Unnecessary cost of treating } \\
\text { clean material as exceeding } \\
\text { waste acceptance criteria. }\end{array}$ & Low to moderate \\
\hline $3-2$ & $\begin{array}{l}\text { The radiological activity of the } \\
\text { material does not exceed the disposal } \\
\text { facility waste acceptance criteria } \\
\text { limits. It will be evaluated for } \\
\text { chemical waste designation and } \\
\text { disposed in an approved facility. }\end{array}$ & $\begin{array}{l}\text { Public may be exposed to } \\
\text { radiological contamination } \\
\text { because the waste exceeds the } \\
\text { design specification of the } \\
\text { disposal facility. }\end{array}$ & Severe \\
\hline $3-3$ & No action. & $\begin{array}{l}\text { Public may be exposed to } \\
\text { radiological contamination. }\end{array}$ & Severe \\
\hline \multicolumn{4}{|c|}{$\begin{array}{l}\text { Decision Statement \#3 - Determine if the material radiological activity exceeds the disposal facility waste } \\
\text { acceptance criteria limits. }\end{array}$} \\
\hline \multicolumn{4}{|c|}{ Principal Study Question \#4 - Is the material land disposal restricted? } \\
\hline 4-1 & $\begin{array}{l}\text { The material is land disposal } \\
\text { restricted. Treatment is imposed on } \\
\text { the material prior to disposal. }\end{array}$ & $\begin{array}{l}\text { Unnecessary cost of treating } \\
\text { material as land disposal } \\
\text { restricted when it is not. }\end{array}$ & Moderate \\
\hline $4-2$ & $\begin{array}{l}\text { The material is not land disposal } \\
\text { restricted. Treatment is not required } \\
\text { for the material prior to disposal. The } \\
\text { material will be disposed in an onsite } \\
\text { facility without treatment. }\end{array}$ & $\begin{array}{l}\text { Public may be exposed to land } \\
\text { disposal restricted waste } \\
\text { because the landfill the waste } \\
\text { is placed in is not designed to } \\
\text { receive this type of waste. }\end{array}$ & Severe \\
\hline 4-3 & No action. & $\begin{array}{l}\text { Public may be exposed to land } \\
\text { disposal restricted waste. }\end{array}$ & Severe \\
\hline \multicolumn{4}{|c|}{ Decision Statement \#4 - Determine if land disposal restrictions impose treatment for material. } \\
\hline \multicolumn{4}{|c|}{$\begin{array}{l}\text { PRINCIPAL STUDY QUESTION \#5 - Does the treated material meet universal treatment standards and } \\
\text { disposal facility waste acceptance criteria limits? }\end{array}$} \\
\hline $5-1$ & $\begin{array}{l}\text { The land disposal restricted material } \\
\text { requires treatment. After treatment, } \\
\text { the material meets the universal } \\
\text { treatment standards and disposal } \\
\text { facility waste acceptance criteria limits } \\
\text { and will be disposed in an approved } \\
\text { facility. }\end{array}$ & $\begin{array}{l}\text { If universal treatment } \\
\text { standards are not met, public } \\
\text { may be exposed to } \\
\text { contamination because the } \\
\text { landfill the waste is placed in } \\
\text { may not designed to receive } \\
\text { this type of waste. }\end{array}$ & Severe \\
\hline
\end{tabular}


Table 1-6. Summary of DQO Step 2 Information. (4 pages)

\begin{tabular}{|c|l|l|c|}
\hline $\begin{array}{c}\text { PSQ- } \\
\text { AA \# }\end{array}$ & \multicolumn{1}{|c|}{ Alternative Action } & $\begin{array}{l}\text { Description of Consequences } \\
\text { of Implementing the Wrong } \\
\text { Alternative Action }\end{array}$ & $\begin{array}{c}\text { Severity of Consequences } \\
\text { (Low/Moderate/Severe) }\end{array}$ \\
\hline $5-2$ & $\begin{array}{l}\text { The land disposal restricted material } \\
\text { requires treatment. After treatment, } \\
\text { the material does not meet the } \\
\text { universal treatment standards and/or } \\
\text { disposal facility waste acceptance } \\
\text { criteria limits. Additional treatment } \\
\text { and sampling is required prior to } \\
\text { disposal. }\end{array}$ & $\begin{array}{l}\text { Performing additional } \\
\text { treatment when it is not } \\
\text { needed. }\end{array}$ & Moderate \\
\hline $5-3$ & $\begin{array}{l}\text { No action. } \\
\text { Decision Statement \#5 - Determine if the treated material meets universal treatment standards and disposal } \\
\text { facility waste acceptance criteria limits. }\end{array}$ & $\begin{array}{l}\text { Public may be exposed to } \\
\text { contamination. }\end{array}$ & Severe \\
\hline
\end{tabular}

\subsection{IDENTIFY INPUTS TO THE DECISION}

Table 1-7 identifies the decision statements where existing data either do not exist or are of insufficient quality to resolve the decision statements. For these decision statements, Table 1-7 also presents computational and/or surveying/sampling methods that could be used to obtain the required data.

Table 1-7. Information Required to Resolve the Decision Statements. (2 pages)

\begin{tabular}{|c|l|l|c|l|}
\hline DS \# & Informational Need & Required Data & $\begin{array}{c}\text { Computational } \\
\text { Methods }\end{array}$ & $\begin{array}{c}\text { Survey/Sampling } \\
\text { Methods }\end{array}$ \\
\hline Ia & $\begin{array}{l}\text { Radiological survey } \\
\text { data for materials }\end{array}$ & $\begin{array}{l}\text { Radiological survey data } \\
\text { for direct counting and } \\
\text { technical smears }\end{array}$ & N/A & $\begin{array}{l}\text { Radiological surveys in } \\
\text { accordance with } \\
\text { BHI-SH-04 }\end{array}$ \\
\hline lb & $\begin{array}{l}\text { Compliance with } \\
\text { radiological release } \\
\text { limits for } \\
\text { volumetrically } \\
\text { contaminated media }\end{array}$ & $\begin{array}{l}\text { Radiological data in pCi/g } \\
\text { or pCi/L }\end{array}$ & N/A & $\begin{array}{l}\text { Media sampling and } \\
\text { analysis }\end{array}$ \\
\hline $2 a$ & $\begin{array}{l}\text { Listed dangerous } \\
\text { waste status }\end{array}$ & $\begin{array}{l}\text { Process knowledge about } \\
\text { materials }\end{array}$ & N/A & $\begin{array}{l}\text { Process knowledge } \\
\text { investigation }\end{array}$ \\
\hline $2 b$ & $\begin{array}{l}\text { Characteristic waste } \\
\text { code status }\end{array}$ & $\begin{array}{l}\text { Process knowledge, and/or } \\
\text { sampling and analysis data }\end{array}$ & N/A & $\begin{array}{l}\text { Process knowledge, } \\
\text { investigation, or media } \\
\text { sampling and analysis }\end{array}$ \\
\hline $2 c$ & $\begin{array}{l}\text { Toxic dangerous } \\
\text { waste code status }\end{array}$ & $\begin{array}{l}\text { Process knowledge, } \\
\text { reference evaluation }\end{array}$ & N/A & $\begin{array}{l}\text { Engineering } \\
\text { investigation }\end{array}$ \\
\hline
\end{tabular}


Table 1-7. Information Required to Resolve the Decision Statements. (2 pages)

\begin{tabular}{|c|c|c|c|c|}
\hline DS \# & Informational Need & Required Data & $\begin{array}{l}\text { Computational } \\
\text { Methods }\end{array}$ & $\begin{array}{c}\text { Survey/Sampling } \\
\text { Methods }\end{array}$ \\
\hline $2 d$ & $\begin{array}{l}\text { Persistent waste code } \\
\text { status }\end{array}$ & $\begin{array}{l}\text { Process knowledge, and/or } \\
\text { sampling and analysis data }\end{array}$ & N/A & $\begin{array}{l}\text { Process knowledge, } \\
\text { investigation, or media } \\
\text { sampling and analysis }\end{array}$ \\
\hline $2 e$ & $\begin{array}{l}\text { Polychlorinated } \\
\text { biphenyl } \\
\text { concentrations }\end{array}$ & $\begin{array}{l}\text { Process knowledge and/or } \\
\text { sampling and analysis data }\end{array}$ & N/A & $\begin{array}{l}\text { Process knowledge, } \\
\text { investigation, or media } \\
\text { sampling and analysis }\end{array}$ \\
\hline $2 f$ & $\begin{array}{l}\text { Asbestos containing } \\
\text { materials }\end{array}$ & $\begin{array}{l}\text { Process knowledge and/or } \\
\text { sampling and analysis data }\end{array}$ & N/A & $\begin{array}{l}\text { Process knowledge, } \\
\text { investigation, or media } \\
\text { sampling and analysis }\end{array}$ \\
\hline 3 & $\begin{array}{l}\text { Radiological } \\
\text { compliance with } \\
\text { disposal facility waste } \\
\text { acceptance criteria }\end{array}$ & $\begin{array}{l}\text { Radiological survey and/or } \\
\text { sampling and analysis data }\end{array}$ & N/A & $\begin{array}{l}\text { Radiological surveys, } \\
\text { and/or media sampling } \\
\text { and analysis }\end{array}$ \\
\hline 4 & $\begin{array}{l}\text { Land disposal } \\
\text { restrictions }\end{array}$ & $\begin{array}{l}\text { Process knowledge and/or } \\
\text { sampling and analysis data }\end{array}$ & N/A & $\begin{array}{l}\text { Process knowledge, } \\
\text { investigation, or media } \\
\text { sampling and analysis }\end{array}$ \\
\hline 5 & $\begin{array}{l}\text { Compliance with } \\
\text { universal treatment } \\
\text { standards and disposal } \\
\text { facility waste } \\
\text { acceptance criteria }\end{array}$ & Sampling and analysis data & N/A & $\begin{array}{l}\text { Sampling and analysis } \\
\text { of treated waste }\end{array}$ \\
\hline
\end{tabular}

Note that process knowledge has eliminated asbestos as a COC for the 183-DR Water Treatment Plant.

\subsection{ANALYTICAL PERFORMANCE REQUIREMENTS}

Table 1-8 defines the analytical performance requirements for the data that need to be collected to resolve each of the decision statements. These performance requirements include the practical quantitation limit (PQL) and precision and accuracy requirements for each of the COCs. 
Table 1-8. Analytical Performance Requirements.

\begin{tabular}{|c|c|c|c|c|c|c|}
\hline $\begin{array}{c}\text { DS } \\
\#\end{array}$ & COCs & $\begin{array}{l}\text { Survey/ } \\
\text { Analytical } \\
\text { Method }\end{array}$ & $\begin{array}{l}\text { Preliminary } \\
\text { Action Level }\end{array}$ & PQL & $\begin{array}{l}\text { Precision } \\
\text { Req't }\end{array}$ & $\begin{array}{c}\text { Accuracy } \\
\text { Req't }\end{array}$ \\
\hline \multirow[b]{2}{*}{1} & $\begin{array}{l}\text { Radionuclides }^{\mathrm{a}} \\
\text { (gross alpha) }\end{array}$ & $\begin{array}{l}\text { Gas proportional } \\
\text { counting }\end{array}$ & $\begin{array}{l}3 \mathrm{pCi} / \mathrm{L} \\
5 \mathrm{pCi} / \mathrm{g}\end{array}$ & $\begin{array}{c}1.5 \mathrm{pCi} / \mathrm{L} \\
5 \mathrm{pCi} / \mathrm{g}\end{array}$ & $\pm 20 \%$ & $\pm 20 \%$ \\
\hline & $\begin{array}{l}\text { Radionuclides }{ }^{\mathrm{a}} \\
\text { (gross } \\
\text { beta/gamma) }\end{array}$ & $\begin{array}{l}\text { Gas proportional } \\
\text { counting }\end{array}$ & $\begin{array}{c}4 \mathrm{pCi} / \mathrm{L} \\
10 \mathrm{pCi} / \mathrm{g}\end{array}$ & $\begin{array}{l}2 \mathrm{pCi} / \mathrm{L} \\
5 \mathrm{pCi} / \mathrm{g}\end{array}$ & $\pm 20 \%$ & $\pm 20 \%$ \\
\hline \multirow{11}{*}{2} & Arsenic (TCLP) & 6010 (ICAP) & $5.0 \mathrm{mg} / \mathrm{L}$ & $2.5 \mathrm{mg} / \mathrm{L}$ & $\pm 20 \%$ & $\pm 20 \%$ \\
\hline & Barium (TCLP) & 6010 (ICAP) & $100 \mathrm{mg} / \mathrm{L}$ & $50 \mathrm{mg} / \mathrm{L}$ & $\pm 20 \%$ & $\pm 20 \%$ \\
\hline & $\begin{array}{l}\text { Cadmium } \\
\text { (TCLP) }\end{array}$ & 6010 (ICAP) & $1.0 \mathrm{mg} / \mathrm{L}$ & $0.5 \mathrm{mg} / \mathrm{L}$ & $\pm 20 \%$ & $\pm 20 \%$ \\
\hline & $\begin{array}{l}\text { Chromium } \\
\text { (TCLP) }\end{array}$ & 6010 (ICAP) & $5.0 \mathrm{mg} / \mathrm{L}$ & $2.5 \mathrm{mg} / \mathrm{L}$ & $\pm 20 \%$ & $\pm 20 \%$ \\
\hline & Lead (TCLP) & 6010 (ICAP) & $5.0 \mathrm{mg} / \mathrm{L}$ & $2.5 \mathrm{mg} / \mathrm{L}$ & $\pm 20 \%$ & $\pm 20 \%$ \\
\hline & Mercury (TCLP) & 7471 (CVAA) & $0.2 \mathrm{mg} / \mathrm{L}$ & $0.1 \mathrm{mg} / \mathrm{L}$ & $\pm 20 \%$ & $\pm 20 \%$ \\
\hline & $\begin{array}{l}\text { Selenium } \\
\text { (TCLP) }\end{array}$ & $6010(\mathrm{ICAP})$ & $1.0 \mathrm{mg} / \mathrm{L}$ & $0.5 \mathrm{mg} / \mathrm{L}$ & $\pm 20 \%$ & $\pm 20 \%$ \\
\hline & Silver (TCLP) & 6010 (ICAP) & $5.0 \mathrm{mg} / \mathrm{L}$ & $2.5 \mathrm{mg} / \mathrm{L}$ & $\pm 20 \%$ & $\pm 20 \%$ \\
\hline & $\mathrm{pH}$ & $9045 \mathrm{C}$ & 2.0 & N/A & $\pm 20 \%$ & $\pm 20 \%$ \\
\hline & Sulfate & 9056 & $250 \mathrm{ppm}$ & $125 \mathrm{ppm}$ & $\pm 20 \%$ & $\pm 20 \%$ \\
\hline & $\begin{array}{l}\text { Polychlorinated } \\
\text { biphenyls }\end{array}$ & $\begin{array}{l}\text { Field screening } \\
\text { test kit }\end{array}$ & $\begin{array}{l}10 \mathrm{ppm} \\
50 \mathrm{ppm}\end{array}$ & $\begin{array}{l}1 \text { ppm in } \\
\text { Soil }\end{array}$ & $\pm 20 \%$ & $\pm 20 \%$ \\
\hline
\end{tabular}

a Soil samples will also be screened for alpha-, beta-, and gamma-emitting radionuclides in the field using field portable instruments by the field sampling team.

CVAA $=$ cold vapor atomic absorption

ICP $=$ inductively coupled plasma

$\mathrm{N} / \mathrm{A}=$ not applicable

\subsection{SCALE OF DECISION MAKING}

In Table 1-9, the scale of decision making has been defined for each decision statement. The scale of decision making is defined by joining the population of interest and the spatial and temporal boundaries of the area under investigation. 
Table 1-9. Scale of Decision Making.

\begin{tabular}{|c|c|l|c|l|l|}
\hline \multirow{2}{*}{ DS \# } & \multirow{2}{*}{$\begin{array}{c}\text { Population of } \\
\text { Interest }\end{array}$} & Spatial Boundary & $\begin{array}{c}\text { Temporal Boundary } \\
\text { Frame }\end{array}$ & $\begin{array}{c}\text { When to Collect } \\
\text { Data }\end{array}$ & $\begin{array}{c}\text { Scale of } \\
\text { Decision }\end{array}$ \\
\hline \multirow{2}{*}{$1-5$} & $\begin{array}{l}\text { Concentration of } \\
\text { COCs in drill cuttings }\end{array}$ & $\begin{array}{l}\text { Interior of the drums } \\
\text { containing drill } \\
\text { cuttings }\end{array}$ & $\begin{array}{l}\text { Clear weather and } \\
\text { low wind speed is } \\
\text { preferred to reduce } \\
\text { chances for worker } \\
\text { exposure. }\end{array}$ & $\begin{array}{l}\text { Interior of the } \\
\text { drums over the } \\
\text { next } 1,000 \\
\text { years }\end{array}$ \\
\hline
\end{tabular}

\subsection{DECISION RULES}

Table 1-10 presents decision rules that correspond to each of the decision statements identified in Table 1-7. Note that process knowledge has eliminated asbestos as a contaminant of concern for the 183-DR Water Treatment Plant. Consequently, no decision rule related to asbestos has been provided.

Table 1-10. Decision Rules. (2 pages)

\begin{tabular}{|c|c|}
\hline DR\# & Decision Rule \\
\hline la & $\begin{array}{l}\text { Potentially surface contaminated materials: } \\
\text { If the maximum, average, or removable (as applicable) radiological release survey results } \\
\left(\mathrm{dpm} / 100 \mathrm{~cm}^{2} \text { ) for materials indicate that the radiological activity does not exceed the survey }\right. \\
\text { release guidelines, then the materials will be evaluated for offsite/onsite disposition per DR } \# 2 \\
\text { through } \mathrm{DR} \# 5 \text {, as applicable. } \\
\text { If the maximum, average, or removable (as applicable) radiological release survey results } \\
\text { (dpm/100 } \mathrm{cm}^{2} \text { ) for materials indicate that the radiological activity exceeds the release guidelines, } \\
\text { then the materials will be evaluated for onsite disposal per DR } \# 3 \text { through DR } \# 5 \text {, as applicable. }\end{array}$ \\
\hline $1 b$ & $\begin{array}{l}\text { Potentially volumetrically contaminated materials: } \\
\text { If the } 95 \% \text { upper confidence limit or single sample concentration (as applicable) radiological } \\
\text { analytical results ( } \mathrm{pCi} / \mathrm{g} \text { or } \mathrm{pCi} / \mathrm{L} \text { ) for potentially volumetrically contaminated materials indicate } \\
\text { that the radiological activity does not exceed the release guidelines in Table } 5-2 \mathrm{a} \text {, then the } \\
\text { materials will be evaluated for offsite/onsite disposition per } \mathrm{DR} \# 2 \text { through } \mathrm{DR} \# 5 \text {, as applicable. } \\
\text { If the } 95 \% \text { upper confidence limit or single sample concentration (as applicable) radiological } \\
\text { analytical results ( } \mathrm{pCi} / \mathrm{g} \text { or } \mathrm{pCi} / \mathrm{L} \text { ) for potentially volumetrically contaminated materials indicate } \\
\text { that the radiological activity exceeds the release guidelines in Table } 5-2 \mathrm{a} \text {, then the materials will be } \\
\text { evaluated for onsite disposal per } \mathrm{DR} \# 3 \text { through } \mathrm{DR} \# 5 \text {, as applicable. }\end{array}$ \\
\hline
\end{tabular}


Table 1-10. Decision Rules. (2 pages)

\begin{tabular}{|c|c|}
\hline DR\# & Decision Rule \\
\hline 2 & $\begin{array}{l}\text { If process knowledge, or the } 80 \% \text { upper confidence limit, or single sample concentrations of the } \\
\text { detected analytical value indicates that the materials do not designate as dangerous, or polychlorinated } \\
\text { biphenyl waste, then the materials will be released for offsite recycle, reuse, or clean landfill disposal. } \\
\text { If process knowledge, or the } 80 \% \text { upper confidence limit, or single sample concentrations of the } \\
\text { detected analytical value indicates that the materials designate as dangerous or polychlorinated } \\
\text { biphenyl waste, then the materials will be evaluated for treatment and onsite disposal per DR \#3 } \\
\text { through DR \#5. }\end{array}$ \\
\hline $3 a$ & $\begin{array}{l}\text { Surface contaminated materials: } \\
\text { If the maximum, average, or removable (as applicable) radiological survey results }\left(\mathrm{dpm} / 100 \mathrm{~cm}^{2} \text { ) }\right. \\
\text { for materials indicate that the radiological activity exceeds the disposal facility waste acceptance } \\
\text { criteria limits, then the materials will be evaluated for chemical waste designation, and disposition } \\
\text { options will be discussed with the regulators. } \\
\text { If the maximum, average, or removable (as applicable) radiological survey results (dpm/100 } \mathrm{cm}^{2} \text { ) } \\
\text { for materials indicate that the radiological activity does not exceed the disposal facility waste } \\
\text { acceptance criteria limits, then the materials will be evaluated for chemical waste designation per } \\
\text { DR \#2. }\end{array}$ \\
\hline $3 b$ & $\begin{array}{l}\text { Potentially volumetrically contaminated items: } \\
\text { If the } 95 \% \text { upper confidence limit or single sample concentration (as applicable) radiological } \\
\text { analytical results ( } \mathrm{pCi} / \mathrm{g} \text { or } \mathrm{pCi} / \mathrm{L} \text { ) for potentially volumetrically contaminated materials indicate } \\
\text { that the radiological activity exceeds the disposal facility waste acceptance criteria limits, then the } \\
\text { materials will be evaluated for chemical waste designation, and disposition options will be } \\
\text { discussed with the regulators. } \\
\text { If the } 95 \% \text { upper confidence limit or single sample concentration (as applicable) radiological } \\
\text { analytical results ( } \mathrm{pCi} / \mathrm{g} \text { or } \mathrm{pCi} / \mathrm{L} \text { ) for potentially volumetrically contaminated materials indicates } \\
\text { that the radiological activity does not exceed the disposal facility waste acceptance criteria limits, } \\
\text { then the materials will be evaluated for chemical waste designation per } \mathrm{DR} \# 2 \text {. }\end{array}$ \\
\hline 4 & $\begin{array}{l}\text { If process knowledge or any detected analytical sample value dictates land disposal restriction imposed } \\
\text { treatment, then treat the materials, resample, and evaluate for disposal per DR } \# 5 \text {. } \\
\text { If process knowledge, or none of the detected analytical sample values dictate land disposal restriction } \\
\text { imposed treatment of the materials, then dispose in an onsite waste disposal facility. }\end{array}$ \\
\hline 5 & $\begin{array}{l}\text { If all detected analytical sample values indicate that treated materials meet the universal treatment } \\
\text { standards and disposal facility waste acceptance criteria limits, then dispose of the treated materials in } \\
\text { an onsite facility. } \\
\text { If any detected analytical sample values indicate that treated materials do not meet the universal } \\
\text { treatment standards, and disposal facility waste acceptance criteria limits, then the treatment/disposal } \\
\text { options will be evaluated. The treated materials may require additional treatment and sampling prior to } \\
\text { disposal. }\end{array}$ \\
\hline
\end{tabular}

Table 1-11 provides a summary of the information used to support the selection between a statistical versus a non-statistical sampling design for each decision statement. The factors that were taken into consideration in making this selection included the time frame over which each of the decision statements applies, the qualitative consequences of an inadequate sampling design, and the accessibility of the facility if resampling is required. 
Table 1-11. Statistical Versus Non-Statistical Sampling Design.

\begin{tabular}{|c|c|c|c|c|}
\hline $\begin{array}{c}\text { DS } \\
\#\end{array}$ & $\begin{array}{c}\text { Time } \\
\text { Frame } \\
\text { (Years) }\end{array}$ & $\begin{array}{c}\text { Qualitative Consequences } \\
\text { of Inadequate Sampling } \\
\text { Design } \\
\text { (Low/Moderate/Severe) }\end{array}$ & $\begin{array}{c}\text { Resampling Access } \\
\text { After Waste Disposal } \\
\text { (Accessible/Inaccessible) }\end{array}$ & $\begin{array}{c}\text { Proposed Sampling } \\
\text { Design (Statistical/ } \\
\text { Non-Statistical) }\end{array}$ \\
\hline 1 & 1,000 & Severe & Inaccessible & Statistical \\
\hline 2 & 1,000 & Severe & Inaccessible & Statistical \\
\hline 3 & 1,000 & Severe & Inaccessible & Statistical \\
\hline 4 & 1,000 & Severe & Inaccessible & Statistical \\
\hline 5 & 1,000 & Severe & Inaccessible & Statistical \\
\hline
\end{tabular}

\subsection{STATISTICAL DESIGNS}

Table 1-12 identifies the null hypothesis that applies to the waste being dispositioned. The term "null hypothesis" refers to the baseline condition of the site, which has been defined based on the historical data and process knowledge identified in the scoping summary report. The null hypothesis states the opposite of what is hoped to be demonstrated.

Table 1-12. Defining the Null Hypothesis.

\begin{tabular}{|l|c|}
\hline \multicolumn{1}{|c|}{ Null Hypothesis Statement } & $\begin{array}{c}\text { Indicate } \\
\text { Selection }\end{array}$ \\
\hline $\begin{array}{l}\text { Waste material is assumed to be contaminated until it is shown to be clean. (Waste stream does } \\
\text { not meet disposal criteria.) }\end{array}$ & $\mathbf{X}$ \\
\hline $\begin{array}{l}\text { Waste material is assumed to be clean until it is shown to be contaminated. (Waste stream does } \\
\text { meet disposal criteria.) }\end{array}$ & \\
\hline
\end{tabular}

\subsection{TOLERABLE LIMITS FOR DECISION ERROR}

For each decision statement, Table 1-13 present the selected statistical design to be implemented (i.e., simple random or systematic), final action level, the boundaries of the gray region, and the probability values to points above and below the gray region that reflect the decision maker's tolerable limits for making an incorrect decision. 
Table 1-13. Tolerable Decision Errors.

\begin{tabular}{|c|c|c|c|c|c|c|c|}
\hline \multirow[b]{2}{*}{ DS \# } & \multirow[b]{2}{*}{ COCs } & \multirow[b]{2}{*}{$\begin{array}{c}\text { Selected } \\
\text { Statistical } \\
\text { Design }\end{array}$} & \multirow[b]{2}{*}{$\begin{array}{l}\text { Statistical } \\
\text { Parameter } \\
\text { of Interest }\end{array}$} & \multirow[b]{2}{*}{$\begin{array}{l}\text { Final Action } \\
\text { Level }\end{array}$} & \multirow[b]{2}{*}{ Gray Region } & \multicolumn{2}{|c|}{$\begin{array}{c}\text { Tolerable Decision } \\
\text { Error }\end{array}$} \\
\hline & & & & & & $\begin{array}{c}\text { At } \\
\text { Lower } \\
\text { Bound of } \\
\text { Gray } \\
\text { Region } \\
(\%)\end{array}$ & $\begin{array}{c}\text { At } \\
\text { Action } \\
\text { Level } \\
(\%)\end{array}$ \\
\hline \multirow{13}{*}{$\begin{array}{l}1,2 \\
3,4 \\
\text { and } 5\end{array}$} & $\begin{array}{l}\text { Radionuclides } \\
\text { (gross alpha) }\end{array}$ & Systematic & Mean & $\begin{array}{l}3 \mathrm{pCi} / \mathrm{L} \\
5 \mathrm{pCi} / \mathrm{g}\end{array}$ & $\begin{array}{l}80 \% \text { action } \\
\quad \text { level }\end{array}$ & $20 \%$ & $5 \%$ \\
\hline & $\begin{array}{l}\text { Radionuclides } \\
\text { (gross } \\
\text { beta/gamma) }\end{array}$ & Systematic & Mean & $\begin{array}{l}4 \mathrm{pCi} / \mathrm{L} \\
10 \mathrm{pCi} / \mathrm{g}\end{array}$ & $\begin{array}{l}80 \% \text { action } \\
\text { level }\end{array}$ & $20 \%$ & $5 \%$ \\
\hline & Arsenic (TCLP) & Systematic & Mean & $5.0 \mathrm{mg} / \mathrm{L}$ & $\begin{array}{l}80 \% \text { action } \\
\text { level }\end{array}$ & $20 \%$ & $5 \%$ \\
\hline & Barium (TCLP) & Systematic & Mean & $100 \mathrm{mg} / \mathrm{L}$ & $\begin{array}{l}80 \% \text { action } \\
\text { level }\end{array}$ & $20 \%$ & $5 \%$ \\
\hline & $\begin{array}{l}\text { Cadmium } \\
\text { (TCLP) }\end{array}$ & Systematic & Mean & $1.0 \mathrm{mg} / \mathrm{L}$ & $\begin{array}{l}80 \% \text { action } \\
\text { level }\end{array}$ & $20 \%$ & $5 \%$ \\
\hline & $\begin{array}{l}\text { Chromium } \\
\text { (TCLP) }\end{array}$ & Systematic & Mean & $5.0 \mathrm{mg} / \mathrm{L}$ & $\begin{array}{l}80 \% \text { action } \\
\text { level }\end{array}$ & $20 \%$ & $5 \%$ \\
\hline & Lead (TCLP) & Systematic & Mean & $5.0 \mathrm{mg} / \mathrm{L}$ & $\begin{array}{l}80 \% \text { action } \\
\text { level }\end{array}$ & $20 \%$ & $5 \%$ \\
\hline & $\begin{array}{l}\text { Mercury } \\
\text { (TCLP) }\end{array}$ & Systematic & Mean & $0.2 \mathrm{mg} / \mathrm{L}$ & $\begin{array}{l}80 \% \text { action } \\
\text { level }\end{array}$ & $20 \%$ & $5 \%$ \\
\hline & $\begin{array}{l}\text { Selenium } \\
\text { (TCLP) }\end{array}$ & Systematic & Mean & $1.0 \mathrm{mg} / \mathrm{L}$ & $\begin{array}{l}80 \% \text { action } \\
\text { level }\end{array}$ & $20 \%$ & $5 \%$ \\
\hline & Silver (TCLP) & Systematic & Mean & $5.0 \mathrm{mg} / \mathrm{L}$ & $\begin{array}{l}80 \% \text { action } \\
\text { level }\end{array}$ & $20 \%$ & $5 \%$ \\
\hline & $\mathrm{pH}$ & Systematic & Mean & 2.0 & $\begin{array}{l}80 \% \text { action } \\
\text { level }\end{array}$ & $20 \%$ & $5 \%$ \\
\hline & Sulfate & Systematic & Mean & $250 \mathrm{ppm}$ & $\begin{array}{l}80 \% \text { action } \\
\text { level }\end{array}$ & $20 \%$ & $5 \%$ \\
\hline & $\begin{array}{l}\text { Polychlorinated } \\
\text { biphenyls }\end{array}$ & Systematic & Mean & $\begin{array}{l}10 \mathrm{ppm} \\
50 \mathrm{ppm}\end{array}$ & $\begin{array}{l}80 \% \text { action } \\
\text { level }\end{array}$ & $20 \%$ & $5 \%$ \\
\hline
\end{tabular}

\subsection{OPTIMAL SAMPLE SIZE THAT SATISFIES THE DATA QUALITY OBJECTIVES}

Table 1-14 presents the total number of samples/measurements required to be collected for varying error tolerances and varying widths of the gray region. Because chromium is the only analyte from the historical data that is regulated, the standard deviation for this analyte (7.0) was used to support the sample size calculations. Because the toxicity characteristic leachate procedure (TCLP) action level for chromium defined in Table $1-13$ is in $\mathrm{mg} / \mathrm{L}$ units, the 
assumption was made that the soil concentration equivalent is approximately 20 times the TCLP action level, or $100 \mathrm{mg} / \mathrm{kg}$. As would be expected, the higher the error tolerances and the wider the gray region, the smaller the number of samples/measurements that are required.

Table 1-14. Sample/Measurement Size Based on Varying Error Tolerances and LBGR.

\begin{tabular}{|c|c|c|c|c|}
\hline & \multicolumn{3}{|c|}{ Mistakenly Concluding < Action Level } \\
\hline & & $\alpha=5 \%$ & $\alpha=10 \%$ & $\alpha=20 \%$ \\
\hline \multicolumn{5}{|c|}{ LBGR $=70 \%$ action level } \\
\hline \multirow{3}{*}{ 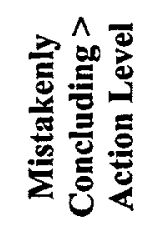 } & $\beta=10 \%$ & 2 & 2 & 1 \\
\hline & $\beta=20 \%$ & 2 & 2 & 1 \\
\hline & $\beta=30 \%$ & 2 & 1 & 1 \\
\hline \multicolumn{5}{|c|}{ LBGR $=80 \%$ action level } \\
\hline \multirow{3}{*}{ 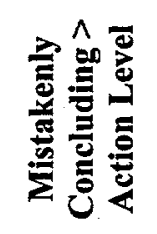 } & $\beta=10 \%$ & 3 & 2 & 1 \\
\hline & $\beta=20 \%$ & 3 & 2 & 1 \\
\hline & $\beta=30 \%$ & 2 & 2 & 1 \\
\hline \multicolumn{5}{|c|}{ LBGR $=90 \%$ action level } \\
\hline \multirow{3}{*}{ 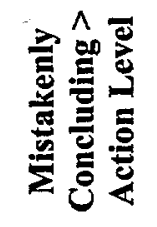 } & $\beta=10 \%$ & 6 & 5 & 3 \\
\hline & $\beta=20 \%$ & 5 & 4 & 2 \\
\hline & $\beta=30 \%$ & 4 & 3 & 2 \\
\hline
\end{tabular}

LBGR = lower bound of gray region

\subsection{SELECTING THE MOST RESOURCE-EFFECTIVE DATA COLLECTION DESIGN}

A trade-off analysis was performed for the purpose of identifying the most resource optimal number of samples/measurements for the given budget. It is important to consider trade-offs so contingency plans can be developed and the added value of selecting one set of considerations over another can be quantified. Table 1-15 identifies the sampling/measurement design that provides the best balance between cost (or expected cost) and the ability to meet the DQOs, and a selection was made. 
Table 1-15. Most Resource-Effective Data Collection Design.

The standard deviation for chromium (7.024) was used in the calculation of the required number of samples and was based on the results from nine historical systematic samples (80-121-10, 80-121-13, 87-122-20,

$110-107-15,118-107-10,130-130-15,130-130-20,131-130-25$, and 136-130-25) collected in the vicinity of the study area. While chromium is the only COC that there is historical data for, other historical analytes (e.g., Al, $\mathrm{Si}, \mathrm{K}, \mathrm{Ca}$, and $\mathrm{Fe}$ ) all showed relatively low standard deviations.

With this understood, the selected sampling design will assume the following:

- Gray region of $80 \%$ of the action level

- Alpha error: $5 \%$

- Beta error: $20 \%$.

While Table 1-14 suggest that only three samples are needed with these assumptions, a total of five systematic samples will be collected to allow for potential larger variances within the population for the other analytes. This is also the smallest number of samples that can be used to run the Wilcoxon Signed Rank test when performing data quality assessment.

\subsection{FINAL STATISTICAL SAMPLING DESIGN}

The results from the trade-off analysis were evaluated for each decision statement. If required, one or more outputs to DQO Steps 1 through 6 were modified to tailor the design to most efficiently meet all of the DQO constraints. Table 1-16 presents a summary of the final statistical design, the total number of samples/measurements to be collected.

Table 1-16. Final Statistical Sampling/Measurement Design. (2 pages)

\begin{tabular}{|c|l|c|}
\hline DS \# & \multicolumn{1}{|c|}{ Statistical Sampling/Measurement Design } & $\begin{array}{c}\text { Number of Samples/ } \\
\text { Measurements }\end{array}$ \\
\hline & $\begin{array}{l}\text { A total of five systematic soil samples will be collected during drilling and } \\
\text { sampling operations from the first of potentially eight boreholes to be drilled } \\
\text { at the 183-DR Water Treatment Plant. These samples will be analyzed for } \\
\text { the COCs identified in Table 1-8. Table 1-8 also identifies the analytical } \\
1,2,3,\end{array}$ & 5 \\
methods that will be run, performance requirements, etc. One sediment 5 & $\begin{array}{l}\text { sample will be collected from borehole \#1 below the water table. } \\
\text { The results from this sampling will be used to characterize the soil from this } \\
\text { borehole for waste disposition. This approach eliminates the need for } \\
\text { sampling waste drums at the completion of drilling operations. }\end{array}$ & \\
\hline
\end{tabular}


Table 1-16. Final Statistical Sampling/Measurement Design. (2 pages)

\begin{tabular}{|c|c|c|}
\hline DS \# & Statistical Sampling/Measurement Design & $\begin{array}{l}\text { Number of Samples/ } \\
\text { Measurements }\end{array}$ \\
\hline & $\begin{array}{l}\text { Because the seven additional boreholes (which may be drilled) are all located } \\
\text { within approximately } 30 \mathrm{ft} \text { from the first borehole, the results from the waste } \\
\text { disposition sampling from the first borehole will also be used to characterize } \\
\text { the waste from the remaining seven boreholes. Process knowledge supports } \\
\text { this approach in that there is no reason to suspect any small ( }<30 \mathrm{ft} \text { ) isolated } \\
\text { spots of contamination present at the site. }\end{array}$ & \\
\hline & $\begin{array}{l}\text { One verification sample will be collected from a random depth interval } \\
\text { within each of the remaining seven boreholes and analyzed for the full suite } \\
\text { of waste disposition analyses identified in Table } 1-8 \text {. }\end{array}$ & \\
\hline & $\begin{array}{l}\text { Because polychlorinated biphenyls are not expected to be present in the } \\
\text { soils, polychlorinated biphenyl analyses will be performed in the field. If } \\
\text { polychlorinated biphenyls are detected using field screening methods, then } \\
\text { confirmation analyses will be run by the offsite laboratory. }\end{array}$ & \\
\hline & $\begin{array}{l}\text { Although there is no reason to suspect volatile organic compounds to be } \\
\text { present at the site, portable organic vapor analyzers will be used to screen } \\
\text { samples in the field to verify, no organics are present. }\end{array}$ & \\
\hline & $\begin{array}{l}\text { A minimum of one duplicate sample will be collected and will be analyzed } \\
\text { for the full suite of analyses identified in Table 1-7. }\end{array}$ & 1 \\
\hline & $\begin{array}{l}\text { A minimum of one equipment rinsate blank sample will be collected to } \\
\text { verify that equipment decontamination procedures are effective. This } \\
\text { sample will be analyzed for the full suite of analyses identified in Table 1-8. }\end{array}$ & 1 \\
\hline & $\begin{array}{l}\text { Standard laboratory quality control analyses shall be implemented as } \\
\text { required by the specified procedures. }\end{array}$ & $\begin{array}{l}\text { As required by } \\
\text { procedures }\end{array}$ \\
\hline
\end{tabular}

\subsection{REFERENCES}

BHI, 1999, 100-D/DR Reactor Area Pipeline Evaluations, (no document number), Bechtel Hanford, Inc., Richland, Washington.

BHI-SH-04, Radiological Control Work Instructions, Bechtel Hanford, Inc., Richland, Washington.

GE, 1952, Design and Construction History, Project C-342, 100-DR Water Plant, General Electric, Richland, Washington.

GE, 1953, Process Specifications Reactor Cooling Water Treatment, HW-28505, General Electric, Richland, Washington.

Thornton, E. C., K. J. Cantrell, J. M. Faurote, T. J Gilmore, K. B. Olsen, and R. Schalla, 2000, Identification of a Hanford Waste Site for Initial Deployment of the In Situ Gaseous Reduction Approach, PNNL-13107, Pacific Northwest National Laboratory, Richland, Washington. 


\section{Attachment 1}

WHC, 1993, 100-D Area Technical Baseline Report, WHC-SD-EN-TI-181, Westinghouse Hanford Company, Richland, Washington. 
Attachment 2

\section{3-DR Site Map}




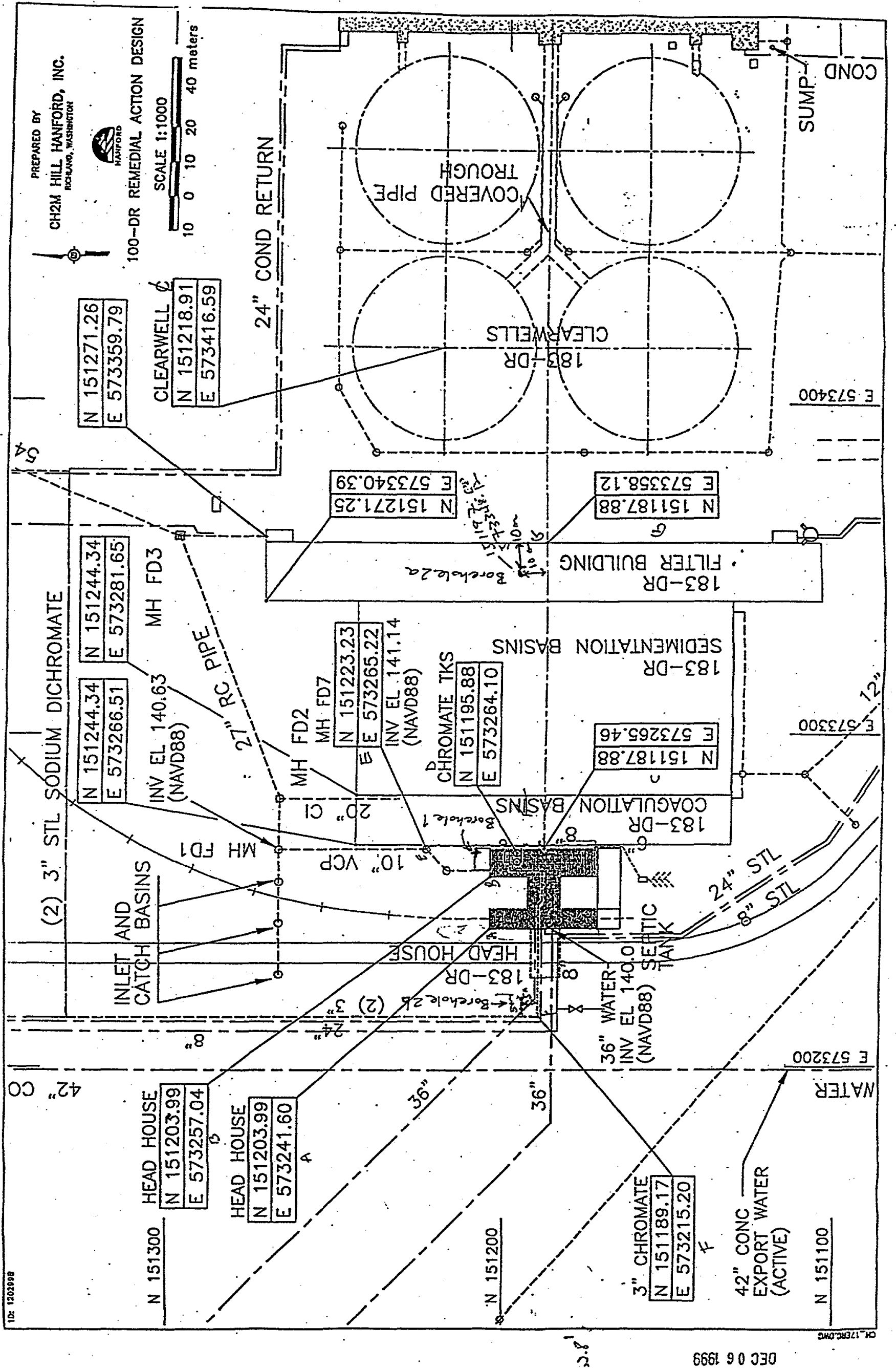


Attachment 3

Borehole SOW and Drilling Specifications 


\section{Exhibit "D" \\ SCOPE OF WORK}

1. SCOPE OF WORK

SUBCONTRACTOR shall perform as detailed in this Exhibit " $D$ ", all preparation, drilling, construction, sampling, development, decontamination, waste handling and other work necessary to provide installation of:

- Two (2) with six (6) optional wells located in the $100 \mathrm{D}$ Area to support a $\mathrm{H}_{2} \mathrm{~S}$ chromium remediation demonstration project.

\section{A. $\mathrm{H}_{2} \mathrm{~S}$ Characterization Vadose Zone/Groundwater Monitoring Well Installations General Description}

Two (2) boreholes for multi-level vadose zone gas monitoring wells will be constructed for the H2S demonstration project under this subcontract. Construction shall consist of 11 -inch boreholes with nominal 10 -inch temporary steel casing to keep the borehole open during drilling and completion. If chromium is discovered in the soil, the borehole will be completed with 5 small diameter screen intakes with 2.0-inch Pipe Size (PS) schedule 40 PVC flush joint risers and wirewrap PVC well screen in the vadose zone and groundwater. All threaded joints shall conform to ASTM F480 flush threaded couplings. The risers shall extend to approximately 2.5 feet above ground surface and 3 to 6 inches below the top of the protective steel casing. Subcontractor to design and provide landing plate and locking cap. Static water level is estimated to range from 80 to 85 feet below ground surface at the proposed drill sites in 100-D Area. Drilling will stop at approximately 90 feet or after passing through 7 feet of the aquifer once the static water table surface is encountered. Each borehole will require soil-sampling efforts on a continuous basis. All intervals penetrated during drilling will be sampled continuously with a nominal 5 -inch diameter, 2.5 foot long, split-spoon sampler. Lexan $\otimes$ liners are to be used in the sampler.

i) General Geology

\section{0-D Area}

The stratigraphic units associated with the unconfined aquifer in the vicinity of the new wells include localized Holocene surficial deposits and backfill, the informally defined Hanford formation, and the Ringold Formation. The first 15-20 feet is made up of backfill material containing broken concrete and reinforcing steel with the last three feet a poured in place reinforced concrete slab. The thickness of the Hanford formation is dominated by gravel with sandy interbeds. Cobble-size clasts are common. Typical thickness of the Hanford formation is in the range of 40 to $60 \mathrm{ft}$ in the 100-D/DR Area. In areas where erosion or excavation has occurred, the Hanford formation may vary.

In the 100-D/DR Area, the Hanford formation disconformably overlies either Ringold Unit $E$ or the Ringold Upper Mud Unit (RUM), depending upon the location. In the vicinity of the new wells, the Hanford formation is in contact with the Ringold Unit $\mathrm{E}$. The bottom of the unconfined aquifer is situated at the top of the less-transmissive RUM. At the new well sites, the saturated thickness is expected to be approximately $20 \mathrm{ft}$, with a 
depth to water (normal river stage) of approximately $80 \mathrm{ft}$ below the ground surface.

In the general area of the new wells, the Hanford/Ringold contact is expected at approximately $55 \mathrm{ft}$ below the surface. The first Ringold sediments encountered should consist of fluvial gravels associated with Ringold Unit $E$ and should persist for approximately the next $45 \mathrm{ft}$ of drilling. Underlying Ringold Unit $\mathrm{E}$ is the RUM, which is a nearly flat lying silt and clay rich unit formed by overbank and paleosol deposits. The RUM contains a few sand and gravel lenses and is commonly calcareous. This unit acts as an aquitard and forms the base of the unconfined aquifer. The RUM is expected at a depth of approximately $100 \mathrm{ft}$ below the surface.

\section{B. Work Included}

The preparation of specified permits, schedules, readying of equipment and personnel, mobilization, drilling and sediment sampling, well construction, development, assisting with aquifer tests, permanent pump installation, decontamination, and demobilization are the key work items of this specific subcontract as executed under the Master Agreement.

\section{Work excluded}

Work specifically excluded is environmental permitting and geologic logging, and to be conducted by the CONTRACTOR or by OTHERS. Geophysical logging will be conducted during the execution of this scope of work.

\section{PREPARATION}

A. SUBCONTRACTOR shall be responsible for the following preparatory activities:

i) Submittals in accordance with this contract two weeks prior to start of work.

ii) Prepare and submit Washington Department of Ecology (WDOE) Notification of Intent to Construct a Monitoring/Resource Protection Well forms and WDOE fee in accordance with WAC 173-160 with a copies of the forms and copies of the payment receipt to the CONTRACTOR.

iii) Prepare and submit at least two weeks before start of drilling for CONTRACTOR review a Site Specific Health and Safety Plan in accordance with 29 CFR 1910.120. All hazards not addressed in the Site Specific Health and Safety Plan shall be addressed in a SUBCONTRACTOR'S Activity Hazard Analysis, or Job Safety Analysis and submitted to CONTRACTOR for review.

iv) Submit worker status reports showing workers meet the SUBCONTRACTOR's required training, medical, bioassay, and qualification expirations. Coordinate training and bioassay needs with CONTRACTOR's STR.

v) Ready equipment, materials and personnel for the execution of this Scope of Work.

\section{CONSTRUCTION}


A. SUBCONTRACTOR shall be responsible for construction of the wells to include mobilization, drilling, sediment sampling, discrete depth aquifer sampling, completion, well abandonment, waste handling, demobilization, and other work necessary to construct the wells in accordance with this contract. Table 1 describes the construction and data requirements for this scope of work.

Two (2) wells shall be installed for the $\mathrm{H}_{2} \mathrm{~S}$ demonstration project. The wells shall be screened within the saturated zone only (screen intervals described in Table 1).

Centralizers shall be used on the saturated screened portion only. SUBCONTRACTOR shall surge the filter pack to settle it. Filter pack and temporary carbon steel casing shall be back pulled to approximately $1 \mathrm{ft}$ above the static water level. Installation of the optional remaining screen intervals and the six additional wells will be made based on analytical results. If the decision is made not to install the remaining screen intervals and additional wells, the boreholes shall be abandon per WAC-173-160. 
Table 1. $\mathrm{H}_{2} \mathrm{~S}$ Generic Well Construction and Sampling Requirements

\begin{tabular}{|c|c|c|c|c|c|c|c|c|c|c|}
\hline $\begin{array}{l}\text { Well } \\
\text { ID No. }\end{array}$ & Well Name & $\begin{array}{c}\text { SAMPLING } \\
\text { REQMTS }\end{array}$ & $\begin{array}{l}\text { Total } \\
\text { Depth } \\
\text { (ft) }\end{array}$ & $\begin{array}{c}\text { Depth- } \\
\text { to- } \\
\text { Water } \\
\text { (' ft) }\end{array}$ & $\begin{array}{c}\text { Screen } \\
\text { Length } \\
\text { (interval) }\end{array}$ & $\begin{array}{c}\text { Filter } \\
\text { Pack } \\
\text { Length } \\
\text { (interval) }\end{array}$ & $\begin{array}{c}\text { Bentonite } \\
\text { Pellet } \\
\text { Seal } \\
\text { Length } \\
\text { (interval) }\end{array}$ & $\begin{array}{l}\text { Well } \\
\text { Type }\end{array}$ & $\begin{array}{c}\text { Cement } \\
\text { Seal } \\
\text { Interval }\end{array}$ & $\begin{array}{c}\text { Comment } \\
* * *\end{array}$ \\
\hline Bxxxx & 199-Dx-xx & $\begin{array}{l}\text { Continuous } \\
\text { split tube } \\
\text { sampling ** }\end{array}$ & 90 & 82 & $\begin{array}{c}10 \\
(17-27)\end{array}$ & $\begin{array}{c}13 \\
(15-28)\end{array}$ & $\begin{array}{c}5 \\
(13-15)\end{array}$ & $\mathrm{H} 2 \mathrm{~S}$ & $0-10^{*}$ & $\begin{array}{l}\text { no air, } \\
\text { or water }\end{array}$ \\
\hline Bxxxx & 199-Dx-xx & $\begin{array}{l}\text { Continuous } \\
\text { split tube } \\
\text { sampling ** }\end{array}$ & 90 & 82 & $\begin{array}{c}10 \\
(35-45)\end{array}$ & $\begin{array}{c}13 \\
(33-46)\end{array}$ & $\begin{array}{c}5 \\
(28-33)\end{array}$ & $\mathrm{H} 2 \mathrm{~S}$ & $0-10^{*}$ & $\begin{array}{l}\text { no air, } \\
\text { or water }\end{array}$ \\
\hline Bxxxx & 199-Dx-xx & $\begin{array}{l}\text { Continuous } \\
\text { split tube } \\
\text { sampling ** }\end{array}$ & 90 & 82 & $\begin{array}{c}10 \\
(53-63)\end{array}$ & $\begin{array}{c}13 \\
(51-64)\end{array}$ & $\begin{array}{c}5 \\
(46-51)\end{array}$ & $\mathrm{H} 2 \mathrm{~S}$ & $0-10^{*}$ & $\begin{array}{l}\text { no air, } \\
\text { or water }\end{array}$ \\
\hline Bxxxx & 199-Dx-xx & $\begin{array}{l}\text { Continuous } \\
\text { split tube } \\
\text { sampling ** }\end{array}$ & 90 & 82 & $\begin{array}{c}10 \\
(71-81)\end{array}$ & $\begin{array}{c}13 \\
(69-82)\end{array}$ & $\begin{array}{c}5 \\
(64-69)\end{array}$ & $\mathrm{H} 2 \mathrm{~S}$ & $0-10^{*}$ & $\begin{array}{l}\text { no air, } \\
\text { or water }\end{array}$ \\
\hline Bxxxx & 199-Dx-xx & $\begin{array}{l}\text { Continuous } \\
\text { split tube } \\
\text { sampling } * *\end{array}$ & 90 & 82 & $\begin{array}{c}10 \\
(79-89)\end{array}$ & $\begin{array}{c}8 \\
(82-90)\end{array}$ & N/A & $\mathrm{H} 2 \mathrm{~S}$ & $0-10^{*}$ & $\begin{array}{l}\text { no air, } \\
\text { or water }\end{array}$ \\
\hline
\end{tabular}

* Only if well is permanently installed.

** Split tube sampling not required the first 20 feet of borehole.

*** Air may be used in the first 20 feet. 


\section{B. Mobilization}

i) Subcontractor shall mobilize drill rig, required equipment and materials to the work site.

ii) Site will be set-up in accordance with SUBCONTRACTOR's Site Specific Health and Safety Plan and/or Activity Hazard Analysis and concurrence of the CONTRACTOR's Field Superintendent.

(1) Establish construction boundaries and restrict access by physical barrier (e.g. yellow rope, construction netting, barricades).

SUBCONTRACTOR shall establish and post the appropriate signs on the work zone (e.g. control area, hard hats, eye protection, hearing protection).

SUBCONTRACTOR shall control access to the work site.

\section{Drilling}

i) SUBCONTRACTOR shall advance the well in accordance with this contract to the depth required to install the specified length of screen below the static water level or abandon as determined by the site geologist.

ii) Well Sampling

(1) Continuous split tube sampling shall be performed. CONTRACTOR to supply split tube samplers. Samples shall be collected in Lexan liners minimum length of 6 in. Subcontractor to supply liners and end caps.

iii) Final Well Completion

(1) SUBCONTRACTOR shall procure and install all permanent material in accordance with this contract.

(a) Set screen and permanent casing in wells

(b) The top of the screen will be set as determined by the CONTRACTOR'S site geologist's interpretation of field conditions.

(c) Settle the filter pack, the CONTRACTOR will determine when development is complete, prior to placing the bentonite plug and/or cement seal.

(d) Install bentonite plug

(e) Install cement seal.

(f) Install surface seal. 
(g) Install surface protection.

(h) Final well development.

D. Waste Handling:

i) SUBCONTRACTOR shall be responsible for packaging, handling, all wastes generated during construction, development, and demobilization in accordance with the Site Specific Waste Management Instruction (Attachment 1 of this scope of work). CONTRACTOR will affix appropriate labels onto the drums once they are sealed, wiped, and moved away from the immediate work area.

CONTRACTOR will transport all regulated waste and purgewater away from the drill site to appropriate disposal and/or storage areas. SUBCONTRACTOR shall collect and dispose of all non-regulated trash and debris associated with the installation, sampling, or other activity associated with this scope of work. The basic containment strategy is as follows:

ii) All soil below static water level may be contaminated with hexavalent chromium, and will be handled in accordance with the SSWMI. All soils above the aquifer shall be contained until analysis of the soil is completed. The CONTRACTOR personnel will analyze a sample of dry drilling spoils for hexavalent chromium. CONTRACTOR personnel will also sample groundwater for hexavalent chromium when the aquifer is encountered. Hexavalent chromium exceeding the release criterion will require all water to be separated from the soil collected. It will be placed in a configuration to allow all residual free water to drain for a period not to exceed 24 hours. The soil, once drained will be placed into performance drums with 10 mil nylon-reinforced plastic liners and anti-corrosive pad, and stored neatly on barrel pallets. All water will be separated from the soil, collected per the SSWMI for eventual transfer into a CONTRACTOR supplied purgewater truck operated by CONTRACTOR.

ii) SUBCONTRACTOR shall provide a forklift for waste relocation where necessary. SUBCONTRACTOR shall allow CONTRACTOR personnel to utilize forklift solely for the purpose of loading palletized waste onto CONTRACTOR owned trucks at the well sites to be hauled by CONTRACTOR personnel to ERDF for burial.

iv) SUBCONTRACTOR shall provide a field decontamination pad, to perform decontamination of the drill, temporary casing, and down hole tools as required by the WAC 173-160. Decon will be performed between holes, and the rinsate will be managed in accordance with the SSWMI.

E. Demobilization 
i) The drill rig derrick, all down-hole equipment and temporary casing shall be field decontaminated (i.e. steam cleaned) prior to leaving the site.

ii) Demobilize all equipment and materials from the site.

iii) Submit Well Reports per WAC 173-160 with a copy to the CONTRACTOR.

\section{OPTIONAL CONSTRUCTION WORK}

\section{A. CONSTRUCTION OF VADOSE ZONE WELLS}

Should hexavalent chromium be detected in the boreholes, the CONTRACTOR will exercise the option to install the remaining wells of Table 1 . The first vadose zone well is installed with the bottom of the 10 foot long well screen one (1) foot above the water table surface, and sand added until the sand pack is two feet above the top of the well screen, but no higher than the bottom of the next higher tubing string. No surging is required for vadose zone wells, the 5 -foot bentonite seal is placed above the sand pack. SUBCONTRACTOR shall continue to place vadose zone wells and backfill this borehole with bentonite or sand at the direction of the CONTRACTOR as shown in Table 1. The borehole shall meet project test requirements for seals and backfilling boreholes. Vertical flow between the completed wells in the borehole must be prevented by adequate seals between each screened interval. The borehole must be designed such that chromium contamination is not spread down the borehole from the drilling or well construction process. This well requires a series of 13-foot thick, sand-packs surrounding 10 foot long 20 slot well screens. Each screen shall have 2 feet of sand pack above the top of each screened interval and 1 foot below the bottom of the well screen. Each 13 foot long sand packed intervals shall be isolated from each other by a 5-foot thick layer of granular bentonite (except for the groundwater well noted in Table 1). The granular bentonite shall be wetted before placing the next layer of sand pack. The final surface seal shall consist of a two-foot thick layer of granular bentonite placed at 13 to 15 feet below ground surface and above the last sand packed well screen interval. As before the layer will be wetted to promote swelling and a seal of the zone. Above this seal shall be placed concrete extending to ground surface forming part of the surface protection.

B. DRILLING SIX ADDITIONAL BOREHOLES AND CONSTRUCTION OF VADOSE ZONE WELLS

Should CONTRACTOR exercise the option for the additional wells, the SUBCONTRACTOR shall drill and construct the wells identified in Table 2. SUBCONTRACTOR shall drill to approximately 90 feet, a water sample shall be taken using a bailer or other acceptable method. SUBCONTRACTOR shall then abandon back to the depth the first well is to be constructed in the vadose zone and shall build the wells.

C. WELL ABANDONMENT AND RESOURCE PROTECTION MONITORING WELL

Should no hexavalent chromium be detected in the boreholes, the CONTRACTOR will 
exercise the option to install one (1) RCRA compliant groundwater monitoring well in one of the boreholes and abandon the other. The monitoring well will be constructed of 4 inch (304) stainless steel with 4 inch (316) stainless steel continuous wire wrap V slot screen and 4 inch riser casing. One (1) split-tube sample shall be collected for screen selection. Screen interval will be $15 \mathrm{ft}$ below the water table and $5 \mathrm{ft}$ above the water table with a $3 \mathrm{ft}$ sump. Bottom of the sump will be installed at approximately $100 \mathrm{ft}$ bgs. Filter pack will be installed $5 \mathrm{ft}$ above the top of the screen. The annulus will be filled with bentonite crumbles with a $10 \mathrm{ft}$ cement surface seal. The borehole that is to be abandoned shall be abandoned in accordance with WAC 173-160. 
Table 2. $\mathrm{H}_{2} \mathrm{~S}$ Generic Well Construction and Sampling Requirements

\begin{tabular}{|c|c|c|c|c|c|c|c|c|c|c|}
\hline $\begin{array}{l}\text { Well } \\
\text { ID No. }\end{array}$ & Well Name & $\begin{array}{c}\text { SAMPLING } \\
\text { REQMTS }\end{array}$ & $\begin{array}{l}\text { Drilling } \\
\text { Total } \\
\text { Depth } \\
\text { (ft) }\end{array}$ & $\begin{array}{c}\text { Depth- } \\
\text { to- } \\
\text { Water } \\
\left.\text { ( }{ }^{\mathrm{b}} \mathrm{ft}\right)\end{array}$ & $\begin{array}{c}\text { Screen } \\
\text { Length } \\
\text { (interval) }\end{array}$ & $\begin{array}{c}\text { Filter } \\
\text { Pack } \\
\text { Length } \\
\text { (interval) }\end{array}$ & $\begin{array}{c}\text { Bentonite } \\
\text { Pellet } \\
\text { Seal } \\
\text { Length } \\
\text { (interval) }\end{array}$ & $\begin{array}{l}\text { Well } \\
\text { Type }\end{array}$ & $\begin{array}{c}\text { Cement } \\
\text { Seal } \\
\text { Interval }\end{array}$ & Comment \\
\hline $\mathrm{Bxxxx}$ & 199-Dx-xx & Grab * & 90 & 82 & $\begin{array}{c}10 \\
(17-27)\end{array}$ & $\begin{array}{c}13 \\
(15-28) \\
\end{array}$ & $\begin{array}{c}5 \\
(13-15) \\
\end{array}$ & $\mathrm{H} 2 \mathrm{~S}$ & $0-10$ & no air \\
\hline Bxxxx & 199-Dx-xx & Grab * & 90 & 82 & $\begin{array}{c}10 \\
(35-45) \\
\end{array}$ & $\begin{array}{c}13 \\
(33-46) \\
\end{array}$ & $\begin{array}{c}5 \\
(28-33) \\
\end{array}$ & $\mathrm{H} 2 \mathrm{~S}$ & $0-10$ & no air \\
\hline Bxxxx & 199-Dx-xx & Grab * & 90 & 82 & $\begin{array}{c}10 \\
(53-63)\end{array}$ & $\begin{array}{c}13 \\
(51-64) \\
\end{array}$ & $\begin{array}{c}5 \\
(46-51) \\
\end{array}$ & $\mathrm{H} 2 \mathrm{~S}$ & $0-10$ & no air \\
\hline Bxxxx & 199-Dx-xx & Grab * & 90 & 82 & $\begin{array}{c}10 \\
(71-81) \\
\end{array}$ & $\begin{array}{c}13 \\
(69-82) \\
\end{array}$ & $\begin{array}{c}5 \\
(64-69) \\
\end{array}$ & $\mathrm{H} 2 \mathrm{~S}$ & $0-10$ & no air \\
\hline
\end{tabular}

Grab samples will be taken every $5 \mathrm{ft}$ from the drill cutting process while advancing borehole. 


\section{Exhibit "E"}

\section{TECHNICAL SPECIFICATIONS}

1. Method

A. SUBCONTRACTOR shall drill, construct the well, and abandon the boreholes according to these specifications, and shall conform to Chapter 173-160 Washington Administrative Code (WAC 173-160), Minimum Standards for Construction and Maintenance of Wells and their approved Health and Safety Program. A variance will be provided, if necessary, by CONTRACTOR.

B. The method of drilling shall be selected by SUBCONTRACTOR and submitted to CONTRACTOR for approval. The SUBCONTRACTOR's selected equipment, tooling, materials and methods shall take into consideration the geologic formations, soil sampling requirements, and control of known or suspected contamination and shall be capable of collecting representative samples for laboratory analysis, allowing for geophysical logging that is representative of actual contamination conditions, advancing the well to the anticipated depth, installing and removing all temporary casing, completing the well, and installing the pump assembly.

i) Excluded methods based on expected impact to data quality objectives are as follows:

(1) Mud or other liquid based (e.g. polymer) circulation systems are not allowed for any of the boreholes. Introduction of air during drilling of high risk intervals and $\mathrm{H}_{2} \mathrm{~S}$ wells is not allowed.

ii) Drilling methods are restricted to a non-circulatory method over the listed intervals. Project sampling requirements and related circulatory requirements are depicted in Exhibit D.

iii) Drilling methods and techniques shall have the capacity to remove all cuttings from the hole. Subcontractor equipment must have the capability of achieving a calculated return velocity of up to $5000 \% / \mathrm{min}$.

iv) SUBCONTRACTOR shall maintain a high degree of dust suppression and control during all phases of the execution of this Subcontract. Water may be added to the borehole to minimize dust at surface, with approval by the CONTRACTOR.

C. The wells shall be straight and plumb. Well straightness test will be performed by the subcontractor and will be verified by the subcontractor by running in temporary casing once hole has been drilled to total depth; with a piece of pipe approximately 20 feet long with 1 " diameter smaller than the inside diameter of the temporary casing. 
A. SUBCONTRACTOR shall supply, but is not limited to, the following equipment and materials necessary to construct the well:

i) Free standing drill rig,

(1) SUBCONTRACTOR shall provide all labor, materials (including temporary casing), equipment, and tooling necessary, except for items specifically listed in Exhibit "B" SC-6.

ii) Drill string.

iii) Appropriate tools.

iv) Tape measures for measuring water level, completion progress, and verifying depth.

v) All temporary construction material.

vi) All permanent construction material.

vii) Dual surge blocks and bailers.

viii) Final development equipment

(1) Temporary pump

(2) Riser tubing

(3) Electrical generator and wiring

(4) Flow meter

(5) Hose

ix) Forklift or other appropriate lifting mechanism for tooling, material and waste handling as necessary.

x) Steam cleaning equipment and materials required to wash drill rigs, drill strings, tools, samplers, etc.

xi) All industrial safety equipment for SUBCONTRACTOR personnel (e.g., eye protection, hard hats, steel-toed footwear, welding hood, face shields, splash protection).

xii) Respiratory protection in accordance with Material Data Safety Sheets (MSDS) and the Subcontractor's Health and Safety plan.

xiii) Appropriate hearing protection for all site personnel.

xiv) Signs, t-posts, and ropes, or other approved barricade for posting zone. Traffic revision barriers and signing.

xv) Fire extinguishers.

xvi) Cellular telephone or other communication device capable of initiating emergency notifications at remote work sites. 
xvii) Portable toilet services located at the drill site and all associated support sites.

xviii) Decontamination pad where all decontamination will be performed while on the Hanford site. All decontamination fluids shall be collected and placed into drums provided by CONTRACTOR.

xix) Trash container for disposal of clean materials such as sand bags, lunch trash, etc.

\section{DRILLING ADDITIVES \& LUBRICANTS}

A. Mudding agents such as bentonite, other clay-based agents, water, foam, polymers, any wetting fluid, or any foreign matter capable of affecting the characteristics of sediment samples or groundwater shall not be placed in the well without prior written approval of the CONTRACTOR.

B. Lubricants used for making up the drill tools and strings, temporary or permanent casings shall be environmentally compatible as per industry standards (e.g., Green-Stuff, OrangeAid, Well Guard).

\section{SEDIMENT SAMPLING}

A. Sediment samples shall be taken in accordance with Exhibit " $D$ ".

B. SUBCONTRACTOR shall retrieve "grab"-type sediment samples in which the geologic character can be documented by CONTRACTOR.

C. SUBCONTRACTOR shall use all means necessary to provide an undisturbed, intact sediment sample that has not been influenced by the drilling method and is relatively free of sluff material for the split-spoon samples and Moisture $/ \mathrm{CaCO}_{3}$ samples. The Moisture $/ \mathrm{CaCO}_{3}$ samples may be taken from the drive barrel as long as the initial criterion has been met.

D. SUBCONTRACTOR shall assemble, drive, retrieve, and open split spoon sampler.

\section{AQUIFER SAMPLE}

A. Aquifer samples shall be taken in accordance with Exhibit "D".

B. SUBCONTRACTOR shall prepare the open face area of the well as best as possible prior to installation of packer, pump and measuring equipment for the purpose of taking a discrete water samples. No discrete sampling is expected for this scope of work.

\section{PERMANENT CASING, SCREEN AND END CAP INSTALLATION AND MATERIALS} $\mathrm{H}_{2}$ S DEMONSTRATION WELLS 
A. Approved materials include for permanent well casings, screen and end caps are:

i) PVC permanent casing (Schedule 40, ASTM D1785, F 480-88a with flushthreaded joints and Viton "O" rings) and PVC screen (ASTM D1785, F 480-88a, continuous wire wrap, with flush-threaded joints and Viton "O" rings); no glues or solvents shall be used. Based on available data, the screen slot size has been preselected at 20-slot.ASTM F480 threaded coupling.

B. All well casings, screens, and other metal items that are part of the final monitoring well must be constructed of similar material (e.g. centralizers on stainless steel casing).

C. SUBCONTRACTOR shall submit certificates of conformance for all permanent well construction materials such as well casing, screen, end cap materials, etc.

D.

D.1.1 For all $\mathrm{H}_{2} \mathrm{~S}$ wells included in this scope of work, 5 individual 2 inch (2.375-inch DO, 2.067-inch ID) PVC casings will be installed in each well as defined in Exhibit D.

D.1.2 Screens shall be 2 inch PVC wire wrap 0.020 (20-slot). Screen length and approximate intervals are depicted Exhibit D.

D.1.3 PVC end cap flush threaded.

E. All connections shall be F480 with flush threaded joints. Viton "O" rings shall be used above the aquifer and may be used within the aquifer.

F. Centering guides (centralizers) shall be placed immediately above and below the screen, and at intervals of 40 feet throughout the casing.

G. All casing, screen, caps, and centralizers shall be cleaned after fabrication at the factory. Cleaning shall consist of washing with a mild detergent, then isopropyl or methanol alcohol, and a clean water rinse. The materials will then be air-dried and wrapped in plastic.

i) Should packaging be damaged during transport or storage the material shall be steam cleaned prior to installation.

H. SUBCONTRACTOR shall inspect all permanent casing, screen, centralizers and end cap and reject defected or flawed materials.

7. PERMANENT CASING, SCREEN AND END CAP INSTALLATION AND MATERIALS OPTIONAL RESOURCE PROTECTION MONITORING WELL

A. Approved materials include for permanent well casings, screen and end caps are:

i) Stainless steel: ASTM A778 or ASTM A312 type 316, or 316L, minimum schedule 5 or equivalent.

B. All well casings, screens, and other metal items that are part of the final monitoring well must be constructed of similar material (e.g. centralizers on stainless steel casing).

C. SUBCONTRACTOR shall submit certificates of conformance for all well casing, screen, 
and end cap materials.

D. Casing shall be 4-inch (316) stainless steel. Screen shall be 4-inch (316) stainless steel, continuous wire wrap 0.020 (20-slot). Screen length and approximate interval are depicted Exhibit D. Stainless steel end cap.

E. All casing, screen, caps, and centralizers shall be cleaned after fabrication at the factory. Cleaning shall consist of washing with a mild detergent, then isopropyl or methanol alcohol, and a clean water rinse. The materials will then be air-dried and wrapped in plastic.

i) Should packaging be damaged during transport or storage the material shall be steam cleaned prior to installation.

\section{PERMANENT PUMP INSTALLATION, OPTIONAL RESOURCE PROTECTION} MONITORING WELL

A. SUBCONTRACTOR shall install sample equipment with the following specifications shall be installed in the $100 \mathrm{D}$ Area monitoring well:

i) Grundfos ${ }^{\mathrm{TM} 1}$ stainless type 5S07-18 pump, single-phase, 220-volt, 0.75horsepower (4-wire).

ii) One-inch diameter galvanized pipe, $\mathrm{T} \& \mathrm{C}(\mathrm{A}-53)$

iii) Two access ports for electrical and e-tape.

iv) Permanent sample pump intake shall be set approximately 1 feet above the bottom of the screen or at the discretion of the well site geologist.

B. SUBCONTRACTOR will "land out" permanent and sampling pump on the top of the protective casing on an appropriate landing plate designed with an access port for E-tape water level instruments.

\section{FILTER PACK INSTALLATION AND MATERIAL}

A. At a minimum the filter material shall consist of kiln dried, rounded and spherical sand composed of at least $95 \%$ silica $\left(\mathrm{SiO}_{2}\right)$. The material shall be packaged and clearly labeled as to the mesh size of the sand contained.

B. Filter pack shall consist of 10 to 20 mesh silica sand shall be placed across screened interval. Approximate screen locations are described in Exhibit " $D$ ".

C. SUBCONTRACTOR shall maintain sufficient overlap during emplacement of filter pack so that native material does not cave into the annulus and contact the permanent casing or screen.

D. The method of settling the filter pack shall be by dual Surge block and bailing technique or other method selected by SUBCONTRACTOR and approved by CONTRACTOR.

i) SUBCONTRACTOR shall fully settle the filter pack so that future settling will not introduce natural or well seal material into the screened interval.

ii) SUBCONTRACTOR shall develop the filter pack to the point where fines 
entering the well are not significant during primary and final development.

\section{WELL SEAL INSTALLATION AND MATERIAL}

A. Well (annular) seals shall strictly follow WAC 173-160-550 with the following changes or additions:

i) The frost zone is conservatively set at 5 feet below surface. A $10^{\prime}$ surface seal will be required.

ii) Bentonite used for sealing purposes shall be made from pellets or chunks consisting of untreated (no surfactants, polymers or peptides) sodium bentonite, packaged and labeled.

iii) Bentonite grout shall be made from Portland cement, bentonite (powder or granules), and raw water.

B. SUBCONTRACTOR shall maintain sufficient overlap during emplacement of well seals so that native material does not cave into the annulus and come in contact with the permanent casing or screen.

\section{SURFACE PROTECTION}

A. Surface protection shall be installed in an "above ground" manner per WAC 173-160-510 with the following additions/modifications:

i) The protective casing shall be a minimum of 2" larger in diameter than the permanent casing. This protective casing shall be:

(1). Stainless steel $(304 / 304 \mathrm{~L} / 304 \mathrm{E})$ or

(2) Schedule 40 Carbon Steel, primed and painted yellow (ANSI Z53.1).

ii) The protective casing shall rise approximately 3 feet above ground surface. The protective casing will be capped with a 15 " lockable cap.

iii) The permanent casing shall rise to approximately one foot below the top of the protective casing.

iv) The protective casing shall have a lockable well cap that extends about 15 inches in height above the top of the protective casing. This allows room to leave dedicated pump fittings and wire attached.

v) Concrete pads shall be 4 feet by 4 feet square by 6 inches thick, steel reinforced with 6" $\times$ 6" W1.4 $\times$ W1.4 welded wire fabric as a minimum.

vi) A brass survey pin with well number inscribed shall be installed on the north side of the pad.

vii) Four protective posts set in concrete around the concrete pad.

(1) Posts shall meet WAC 173-160-510(2)(a) with one post (four per well pad) that is removable. Primed and painted yellow (ANSI Z53.1) 


\section{FINAL WELL DEVELOPMENT}

A. H2S WELLS

The method of settling the filter pack in the $\mathrm{H}_{2} \mathrm{~S}$ groundwater wells shall be by dual surge block and bailing technique or other method selected by SUBCONTRACTOR and approved by CONTRACTOR.

i) SUBCONTRACTOR shall fully settle the filter pack so that future settling will not introduce natural or well seal material into the screened interval.

ii) SUBCONTRACTOR shall develop the filter pack to the point where fines entering the well are not significant during primary and final development. Because each boring will also have a well nest containing 4 vadose zone wells, the SUBCONTRACTOR shall not make a special effort to settle or develop the filter pack in these wells. However, sand bridges (should they occur) must be broken so that the sand settles into the planned areas for placement around the well screen and approved by CONTRACTOR.

\section{B. OPTIONAL RCRA MONTIORING WELL}

SUBCONTRACTOR shall perform final well development by pumping the well. Development shall continue until the well produces clear water, $<5$ NTU as measured by a turbidity meter and the water temperature, $\mathrm{pH}$, and conductivity have stabilized, as indicated by three consecutive measurements within 10 percent of each other. Should these conditions not be met, the CONTRACTOR shall determine when the development is adequate.

It may be necessary to set pump in two areas during final development to fully develop entire screen section.

SUBCONTRACTOR shall notify the CONTRACTOR 24 hours prior to the anticipated final development time in order to arrange for purgewater transportation, hydrogeology support and other support necessary to implement final development.

Final well development shall not be initiated sooner than 12 hours following placement of the annular grout seal.

\section{DECONTAMINATION AND CLEANING}

A. The drill rig, derrick, and all drilling equipment including temporary casings shall be steam cleaned without additives before, after and when necessary during construction of each well in a manner such that visible oils, grease, and dirt are removed.

B. All development and permanent sampling equipment shall be steam cleaned prior to installation.

C. All decontamination and steam cleaning events shall be recorded on an Equipment Decontamination Form.

D. If necessary, subcontractor will construct a decontamination pad to collect dirt, grease, oil, etc. 


\section{HANDLING AND STORAGE OF MATERIAL}

A. The SUBCONTRACTOR shall use all means necessary to protect well construction materials, development, and sampling pump materials before, during, and after installation. All materials shall be stored in their original containers until needed for construction.

B. Personnel handling that portion of the permanent screen or casing that will be placed into the aquifer shall wear clean cotton or latex gloves.

15. WASTE DISPOSAL

A. SUBCONTRACTOR shall contain and dispose of all construction, well development, and demobilization generated trash, to include lunchroom type garbage in accordance with the Site Specific Waste Management Instruction or Waste Control Plan.

B. Drill cuttings, purgewater, associated trash will be handled in accordance with the Site Specific Waste Management Instruction or Waste Control Plan.

i) If soil containment is required the SUBCONTRACTOR shall mark the drums and move them to a waste accumulation area in accordance with the appropriate waste management document. SUBCONTRACTOR shall wipe drums clean prior to labeling. Waste containers will be placed in an orderly manner in this area.

ii) If water containment is required, the SUBCONTRACTOR shall segregate all free water from soil and dispose of water in a CONTRACTOR provided and operated purgewater truck. The water shall be essentially clear and absent of mud and heavy silt prior to loading into purgewater truck.

iii) CONTRACTOR will be responsible for the management and disposal of the drummed waste generated.

\section{QUALITY ASSURANCE}

SUBCONTRACTOR shall perform all work in accordance with their approved Quality Assurance Program.

\section{PERSONNEL}

A. SUBCONTRACTOR'S driller shall:

i) Be a licensed well driller per the Washington State Water Well Construction Act (1971).

ii) Have a minimum of three (3) years experience as a driller with at least one (1) year of which was on a similar rig.

iii) Work to and be knowledgeable of new Chapter 173-160 WAC changes.

iv) SUBCONTRACTOR shall submit the driller's resume to the CONTRACTOR prior to start of work. 
B. A licensed driller shall be at the job site (work site) while well construction work is being conducted.

C. The SUBCONTRACTOR shall ensure all site workers have read and documented having read this Exhibit "E" with all attachments.

\section{ATTACHMENTS}

A. Location maps 
Attachment 4

Variance Request 


\title{
VARIANCE REQUEST in Accordance with WAC 173-160-406
}

\author{
A. Name, address, and phone number of person requesting variance: \\ Ronald Schalla; 3110 Port of Benton Blvd., Richland Wa. 99352; 376-5064 \\ B. Address of the Well site: \\ 100-D Area, Hanford Site, Richland Washington \\ C. $1 / 4,1 / 4$ section, township, range: \\ All of the resource protection wells will be located within the NW $1 / 4$ of the SE $1 / 4$ of the NE $1 / 4$ of \\ Section 22, Township 14 North, Range 26 East \\ D, E, and F. The specific regulations that cannot be followed; comparable alternative \\ specifications; and justification for the request follows:
}

\section{WAC 173-160-420 (3) Nested resource protection wells are prohibited}

The specific design required for effective remediation of hexavalent chromium in the vadose zone at 100-D/DR on the Hanford Site using In Situ Gaseous Reduction (ISGR) technology requires the use of nested wells. This approach involves the preparation of the reactive gas mixture (diluted hydrogen sulfide in air or nitrogen) and its injection into chromatecontaminated soil through a vadose zone well that is located in the center of the well array. The hydrogen sulfide mixture is drawn through the soil by a vacuum applied to six extraction wells situated in a hexagonal array at the periphery of the flow cell. As the gas mixture contacts the contaminated soil, hexavalent chromium is reduced to the trivalent oxidation state, which results in immobilization and detoxification of the chromium. Residual hydrogen sulfide is then scrubbed from the extracted gas mixture by the gas treatment system and the clean air or nitrogen released to the site environment.

A small-scale field demonstration of this approach was previously demonstrated by PNNL at a small waste site located at the U.S. Department of Defense (DoD), HELSTF facility at the White Sands Missile Range, New Mexico. One of the findings was that strata within the zone did not clean up uniformly. To remedy this deficiency during future demonstrations there will be four injection zones in the injection well, and four extraction zones in each of the six extraction wells. The depths of these screened intervals are shown in Table 1 for the injection well and Table 2 for the extraction wells. A diagram of a typical completion is shown in Figure 1. It is important to note that only the injection well will have an additional screened interval in the groundwater zone for monitoring chemistry changes in the groundwater. These nested vadose zone wells will be screened in 10-foot intervals at four depths using 2-in. diameter schedule 40 PVC casing and PVC wire-wrap well screen in each of the boreholes. Filter sand will extend from one foot below to two feet above each well screen interval. Each zone will be separated by a 5 foot thick bentonite seal consisting of sodium bentonite pellets and granules. The pellets will be moistened after placement to facilitate swelling and sealing of the annulus. By having these nested wells and using a series of valves and manifolds, it will be possible to adjust the amount of flow into each layer. As the first layer begins to cleanup, more of the hydrogen sulfide mixture can be directed into zones that require more extensive remediation. In addition, to the four vadose zone wells in each borehole, a 10 foot well screen will be set into the top of the aquifer. The purpose of these groundwater wells is to determine the initial concentrations of groundwater contamination for optimum placement of the vapor extraction 
well network, and to give a before and after picture of the effectiveness of the remediation activity on reducing groundwater concentrations. No gases will be introduced into the groundwater to reduce chromium contamination, but reduction will occur by the immobilization of the chromium in the vadose zone, which is the source of groundwater contamination.

It is our contention that the design is necessary for effective remediation, and none of its features would have a deleterious effect on the aquifer. The proposed annular seal methods would be adequate until decommissioning of the well system. Decommissioning would take place after its use or up to a maximum of 5 years. Therefore, a request is made that the Washington State Department of Ecology grants a variance from the prohibition of nested wells.

\section{WAC 173-160-460 What is the decommissioning process for resource protection wells?}

Within 5 years after use for remediation of the chromium contamination, cement grout will be used to fill the vadose zone wells during decommissioning. Section 1 states that resource protection wells that were not constructed in accordance with these regulations, shall be decommisssioned by an approved casing perforation and grouting method or by extraction of the casing and grouting. Section 2 states "If it can be verified through a field examination and review of the drilling report that the resource protection well was constructed in accordance with these regulations (including an approved variance), it shall be decommissioned by filling from bottom to land surface with bentonite, cement grout or neat cement." We request that Section 2 apply rather than Section 1. First, perforation of PVC casing under Section 1 would likely make decommissioning less effective because of the PVC tendency to break apart during the perforation process. Second it is not practical to pull the PVC out of the concrete surface seal because of its low tensile strength. The wells were designed for easy decommissioning by having 10 foot long screens with 0.020-inch slot openings and 10-20 mesh filter pack and fitting them with NPT threaded ends for ease of use and pressure grouting. The sand pack will extend only one foot below the well screen and two feet above. Therefore, it is assumed that Section 2 will apply rather than the perforation requirements in Section 1 . Specifically, perforation above the screen will not be required if the wells are pressure grouted with cement slurry. Mixture of cement and water should be sufficiently thin to flow yet produce an effective seal, and filled from bottom to top of the screen. The volume should be a minimum of 1.5 times the estimated volume of the well screen, pipe, and filter pack. This method of decommissioning will facilitate not only sealing the casing and 10 foot screen, but also enable effective sealing of the 13 foot long sand pack.

It is our contention that the proposed well design and method of decommissioning will facilitate sealing, and it would not present any adverse effect on the integrity of the annular seal. We request a variance that our design for decommissioning be permitted under Section 2, which does not require perforation or pulling (extraction) of the casing.

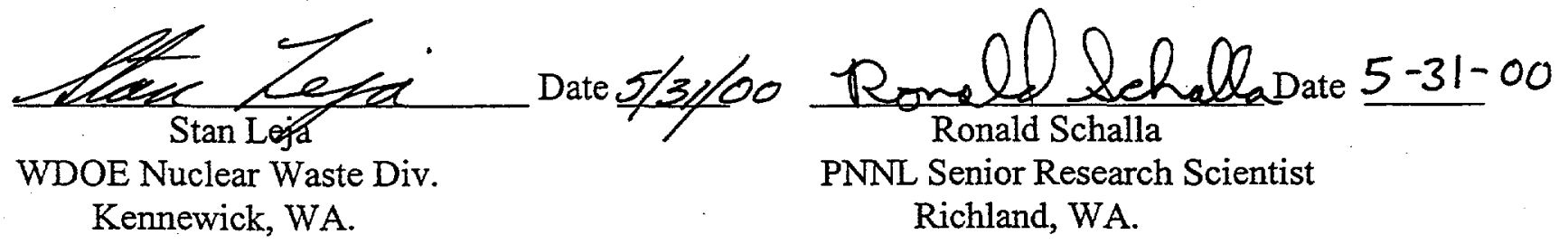



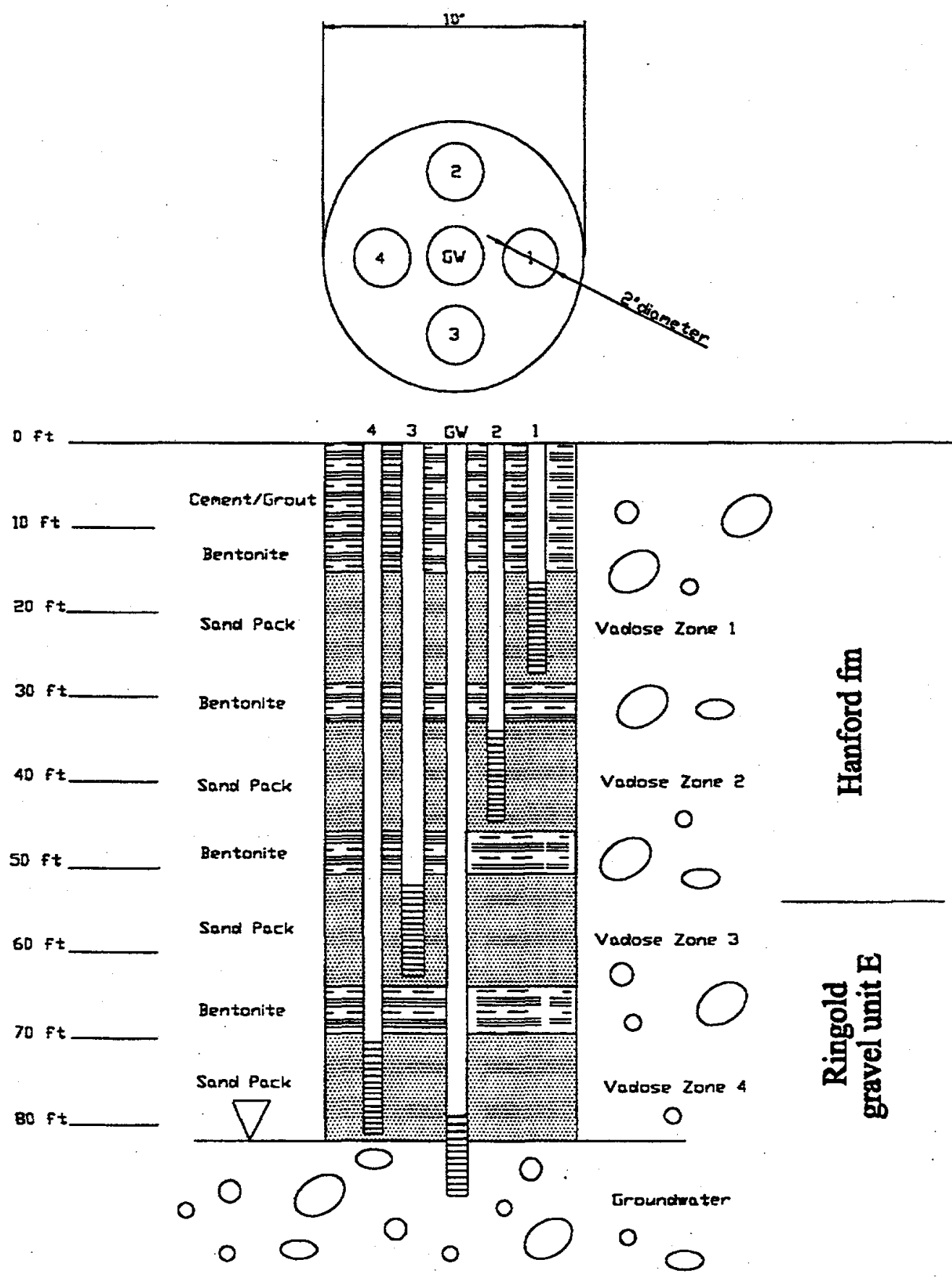

Figure 1. Typical Nested Well Completion for ISGR

Note: Groundwater well installed only in the injection well. 
Table 1. ISGR Generic Injection Well Construction

\begin{tabular}{|l|l|l|c|c|c|c|c|}
\hline $\begin{array}{c}\text { Borehole } \\
\text { or Well } \\
\text { ID No. }\end{array}$ & $\begin{array}{c}\text { Nested } \\
\text { Well } \\
\text { Name }\end{array}$ & $\begin{array}{l}\text { Drilling } \\
\text { Total } \\
\text { Depth (ft) }\end{array}$ & $\begin{array}{c}\text { Estimated } \\
\text { Depth-to- } \\
\text { Water (ft) }\end{array}$ & $\begin{array}{c}\text { Screen } \\
\text { Length } \\
\text { (interval } \\
\text { depths) }\end{array}$ & $\begin{array}{c}\text { Filter Pack } \\
\text { Length } \\
\text { (interval } \\
\text { depths) }\end{array}$ & $\begin{array}{c}\text { Bentonite } \\
\text { Pellet Seal } \\
\text { Length } \\
\text { (interval } \\
\text { depths) }\end{array}$ & $\begin{array}{c}\text { Surface } \\
\text { Cement Seal } \\
\text { Length } \\
\text { (depth } \\
\text { interval) }\end{array}$ \\
\hline Bxxxx & $\begin{array}{l}\text { Upper- } \\
\text { most }\end{array}$ & 90 & 82 & 10 & 13 & 5 & 10 \\
$(17-27)$ & $(15-28)$ & $(13-15)$ & (0-10) \\
\hline Bxxxx & $\begin{array}{l}\text { Upper } \\
\text { Middle }\end{array}$ & $\begin{array}{c}\text { Same } \\
\text { borehole }\end{array}$ & $\begin{array}{c}\text { Same } \\
\text { borehole }\end{array}$ & $\begin{array}{c}10 \\
(35-45)\end{array}$ & $\begin{array}{c}13 \\
(33-46)\end{array}$ & $\begin{array}{c}5 \\
(28-33)\end{array}$ & Same borehole \\
\hline Bxxxx & $\begin{array}{l}\text { Lower } \\
\text { Middle }\end{array}$ & $\begin{array}{c}\text { Same } \\
\text { borehole }\end{array}$ & $\begin{array}{c}\text { Same } \\
\text { borehole }\end{array}$ & $\begin{array}{c}10 \\
(53-63)\end{array}$ & $\begin{array}{c}13 \\
(51-64)\end{array}$ & $\begin{array}{c}5 \\
(46-51)\end{array}$ & Same borehole \\
\hline Bxxxx & $\begin{array}{l}\text { Lower- } \\
\text { most }\end{array}$ & $\begin{array}{c}\text { Same } \\
\text { borehole }\end{array}$ & $\begin{array}{c}\text { Same } \\
\text { borehole }\end{array}$ & $\begin{array}{c}10 \\
(71-81)\end{array}$ & $\begin{array}{c}13 \\
(69-82)\end{array}$ & $\begin{array}{c}5 \\
(64-69)\end{array}$ & Same borehole \\
\hline Bxxxx & $\begin{array}{l}\text { Ground } \\
\text { Water }\end{array}$ & $\begin{array}{c}\text { Same } \\
\text { borehole }\end{array}$ & $\begin{array}{c}\text { Same } \\
\text { borehole }\end{array}$ & $\begin{array}{c}10 \\
(79-89)\end{array}$ & $\begin{array}{c}8 \\
(82-90)\end{array}$ & $\begin{array}{c}\text { None } \\
\text { Same borehole }\end{array}$ \\
\hline
\end{tabular}

*Only if well is permanently installed.

Table 2. ISGR Generic Extraction Well Construction

\begin{tabular}{|l|l|l|l|c|c|c|c|}
\hline $\begin{array}{c}\text { Borehole } \\
\text { or Well } \\
\text { ID No. }\end{array}$ & $\begin{array}{c}\text { Nested } \\
\text { Well } \\
\text { Name }\end{array}$ & $\begin{array}{l}\text { Drilling } \\
\text { Total } \\
\text { Depth (ft) }\end{array}$ & $\begin{array}{c}\text { Estimated } \\
\text { Depth-to- } \\
\text { Water (ft) }\end{array}$ & $\begin{array}{c}\text { Screen } \\
\text { Length } \\
\text { (interval } \\
\text { depths) }\end{array}$ & $\begin{array}{c}\text { Filter Pack } \\
\text { Length } \\
\text { (interval } \\
\text { depths) }\end{array}$ & $\begin{array}{c}\text { Bentonite } \\
\text { Pellet Seal } \\
\text { Length } \\
\text { (interval } \\
\text { depths) }\end{array}$ & $\begin{array}{c}\text { Cement Seal } \\
\text { Length } \\
\text { (depth } \\
\text { interval) }\end{array}$ \\
\hline Bxxxx & $\begin{array}{l}\text { Upper- } \\
\text { most }\end{array}$ & 90 & 82 & $\begin{array}{c}10 \\
(17-27)\end{array}$ & $\begin{array}{c}13 \\
(15-28)\end{array}$ & $\begin{array}{c}5 \\
(13-15)\end{array}$ & $\begin{array}{c}\text { Surface } \\
(0-10)\end{array}$ \\
\hline Bxxxx & $\begin{array}{l}\text { Upper } \\
\text { Middle }\end{array}$ & $\begin{array}{c}\text { Same } \\
\text { borehole }\end{array}$ & $\begin{array}{c}\text { Same } \\
\text { borehole }\end{array}$ & $\begin{array}{c}10 \\
(35-45)\end{array}$ & $\begin{array}{c}13 \\
(33-46)\end{array}$ & $\begin{array}{c}5 \\
(28-33)\end{array}$ & Same borehole \\
\hline Bxxxx & $\begin{array}{l}\text { Lower } \\
\text { Middle }\end{array}$ & $\begin{array}{c}\text { Same } \\
\text { borehole }\end{array}$ & $\begin{array}{c}\text { Same } \\
\text { borehole }\end{array}$ & $\begin{array}{c}10 \\
(53-63)\end{array}$ & $\begin{array}{c}13 \\
(51-64)\end{array}$ & $\begin{array}{c}5 \\
(46-51)\end{array}$ & Same borehole \\
\hline Bxxxx & $\begin{array}{l}\text { Lower- } \\
\text { most }\end{array}$ & $\begin{array}{c}\text { Same } \\
\text { borehole }\end{array}$ & $\begin{array}{c}\text { Same } \\
\text { borehole }\end{array}$ & $\begin{array}{c}10 \\
(71-81)\end{array}$ & $\begin{array}{c}13 \\
(69-82)\end{array}$ & $\begin{array}{c}5 \\
(64-69)\end{array}$ & Same borehole \\
\hline
\end{tabular}




\section{Distribution}

No. of

Copies

ONSITE

4 DOE Richland Operations Office

G. I. Goldberg

$\mathrm{H} 0-12$

J. P. Hanson

K. M. Thompson

A. C. Tortoso

Washington Department of Ecology

W. W. Soper

B5-18

11 Bechtel Hanford, Inc.

J. G. April

H0-17

K. R. Fecht

R. L. Jackson (5)

J. M. Jimenez

G. B. Mitchem

S. W. Petersen

V. J. Rohay

CH2M Hill Hanford, Inc.

M. H. Sturges
No. of

Copies

51 Pacific Northwest National Laboratory

W. F. Bonner

K9-14

J. G. Bush

K6-96

K. J. Cantrell

K6-81

J. L. Devary

K6-96

M. W. Fullmer

P7-28

J. S. Fruchter

K6-96

T. J Gilmore

K6-81

M: J. Hartman

K6-96

K. B. Olsen

K6-96

R. Schalla

K6-96

R. M. Smith

K6-96

F. A. Spane

K6-96

E. C. Thornton (30)

K6-96

B. A. Williams

K6-81

M. D. Williams

K9-36

Information Release (7) 